Systematic review

\title{
Effects of different methods of strength training on indicators of muscle fatigue during and after strength training: a systematic review
}

\author{
Guillermo D. Barahona-Fuentes ${ }^{1}$ (i), Álvaro Huerta Ojeda ${ }^{1,3}$ (i), Daniel Jerez-Mayorga ${ }^{2}$ (D) \\ ${ }^{1}$ Universidad de Las Américas, Grupo de Investigación en Salud, Actividad Física y Deporte, Escuela de Educaci- \\ ón Física, Viña del Mar, Chile; ${ }^{2}$ Universidad Andres Bello, Facultad de Ciencias de la Rehabilitación, San- \\ tiago, Chile; ${ }^{3}$ Centro de Capacitación e Investigación Deportiva Alpha Sports, Valparaiso, Chile.
}

\begin{abstract}
Introduction: The development of strength has shown to be beneficial to sports performance and health. However, during strength training, they also produce alterations in muscle fatigue indicators, leading to a decrease in the ability to generate strength. Despite this, there is still not enough knowledge about the levels of muscle fatigue generated by different methods of strength training and how this information can be integrated into sports planning. Review and analyze the studies existing between January 2009 and January 2019 that have used indicators of muscle fatigue established in the search terms during and after strength training as measurement variables. Evidence acquisition: The study corresponds to a systematic review of previously published studies, following the PRISMA model. Articles published between 2009 and 2019 that measured muscle fatigue indicators during and after strength training were evaluated. The electronic search was conducted through Web of Science, Scopus, Sport Discus, PubMed, and Medline. We included all articles that used a strength protocol and also measured indicators of muscle fatigue and its possible effect on physical performance. Evidence synthesis: A total of 39 articles were found, which were stratified according to the protocol used: (i) plyometric training, (ii) Bodypump ${ }^{\circledR}$ training, (iii) occlusion training, (iv) variable resistance training, (v) conventional strength training, (vi) eccentric strength training, (vii) rest times in strength training and (viii) concurrent training. Conclusion: At the end of the systematic review, it was shown that the different training methodologies for strength development generate increases in muscle fatigue indicators, and the increase generated in the different muscle fatigue indicators depends both on the methodology used and on the type of population, sex, level of training and type of sport. The most-reported indicators are [La], HR and RPE, DOM, MR variation, and ammonium.
\end{abstract}

Keywords: strength training; muscle fatigue indicators; sports performance.

\section{Introduction}

Today, sports training is based on the development of the various manifestations of force ${ }^{1}$. Thus, several investigations have recognized muscle strength as the main capacity to produce a high level of muscle power ${ }^{1,2}$ and neuronal adaptations ${ }^{3}$, which favor the development of muscular hypertrophy ${ }^{4}$. In this sense, optimal muscle development has been associated with sports performance and a better quality of life $\mathrm{e}^{5}$. On the contrary, a decrease in muscle strength and neuromuscular control change the functional behavior of an athlete, limiting performance and possibly triggering an injury ${ }^{6}$.

In order to achieve optimal development of strength, power and muscular hypertrophy, traditional ${ }^{7-13}$ and non-traditional training methods have been used, including plyometric exercises on land ${ }^{14-18}$, plyometrics in the aquatic environment ${ }^{19}$, occlusion training ${ }^{20-23}$, training with elastic bands $^{24}$, electrostimulation training ${ }^{11}$, eccentric exercises ${ }^{25}$, and Bodypump ${ }^{\circledR}$ programs ${ }^{26,27}$. These methods have demonstrated, in several cases, increases in sports performance $e^{4,25,27}$. However, it has also been documented that strength training produces alterations in muscle fatigue indicator ${ }^{28-30}$. In this sense, fatigue has been defined as a reduction in the ability of the neuromuscular system to generate strength or to carry out work resulting from physical exercise $\mathrm{e}^{31,32}$. Thus, a decrease in the production of strength, in its different manifestations during and after strength training, has been associated with increases in blood uric acid ${ }^{33}$, ammonium ${ }^{32}$, lactate concentrations $([\mathrm{La}])^{34}$, elevated heart rate $(\mathrm{HR})^{16}$, increased perception of effort (RPE) ${ }^{35}$, increased muscle pain (DOMS) $)^{36}$, and decreased range of motion (ROM) ${ }^{17}$. These metabolic and physiological responses produced by strength exercise ${ }^{37}$ have been identified as synonymous with fatigue ${ }^{17,32,33}$.

However, it is not yet fully established if these fatigue indicators always produce a decrease in performance ${ }^{26}$. That is why there is a need to establish whether indicators of muscle fatigue are constantly associated with a decrease in performance. As a result of the above, the objective of this systematic review was to review and analyze the studies existing between January 2009 and January 2019 that have used indicators of muscle fatigue established in the search terms during and after strength training as measurement variables. As a secondary objective, the programs were described, establishing the biochemical and physiological responses reported in each of the studies consulted. 
search. Two authors searched and reviewed the studies, both of whom decided whether the inclusion of studies was appropriate. In case of disagreennent, a third author was consulted. The search Procedure

The search identified articles published in the following databases: Web of Science (WOS), Scopus, Sport Discus, PubMed, and Medline. The search limits were: articles published in the in English, Portuguese, French, German, or Spanish.

\section{Bibliographic search}

The literature search was performed in accordance with the guidelines for the Preferred Reporting Items for Systematic Reviews and Meta-Analyses (PRISMA) ) $^{38}$. The title, abstract, and keyword search fields were searched in each of the databases. The OR) were ued: (["Amm "OR "Ammonerato (AND/ OR) were used: ("Ammonium" OR "Ammonium lactate" OR "Aactic acid" OR "Lactace" OR "Acid-base equilibrium" $O R$ "Muscle fatigue" OR "Ratings of perceived exertion" OR "RPE scale"] AND ["Sports performance" OR "Athletic performance"] AND ["Strength training" OR "Resistance training" OR "Force training" OR "Concurrent training" OR "Isometric training" OR "Isokinetic training" OR "Concentric training" OR "Eccentric training" OR "Velocity based training" OR "Complex training" methods of fatigue and force had the purpose of broadening the

\section{Inclusion criteria}

The importance of each study was evaluated according to the following inclusion criteria: a) experimental study design; b) healthy subjects of both genders; c) studies with strength training protocols; d) studies reporting indicators of muscle fatigue through ammonia, lactate, $\mathrm{pH}, \mathrm{HR}$, muscle fatigue and perception of effort; e) those with increased or decreased per-

formance post-interve an. Studies that did not

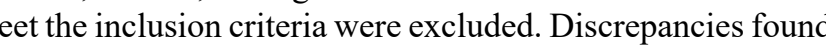
were resolved by consensus of the investigators.

Evaluation of methodological quality

The Physiotherapy Evidence Database (PEDro) scale (39,40 $^{39}$ was used to assess study quality. The classification was based on three criteria: selection (maximum three stars), comparability (maximum three stars), and results (maximum four stars). Articles scoring eight to ten were considered to be of high methodological quality, four to seven moderate, and less than four low. Thus, the score obtained by the articles according to the and 26 articles obtained a moderate score (Table 1$)$.

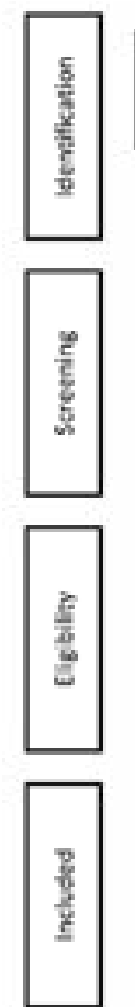

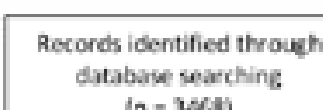

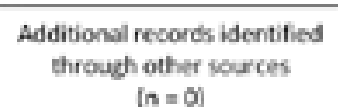

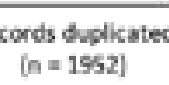

(
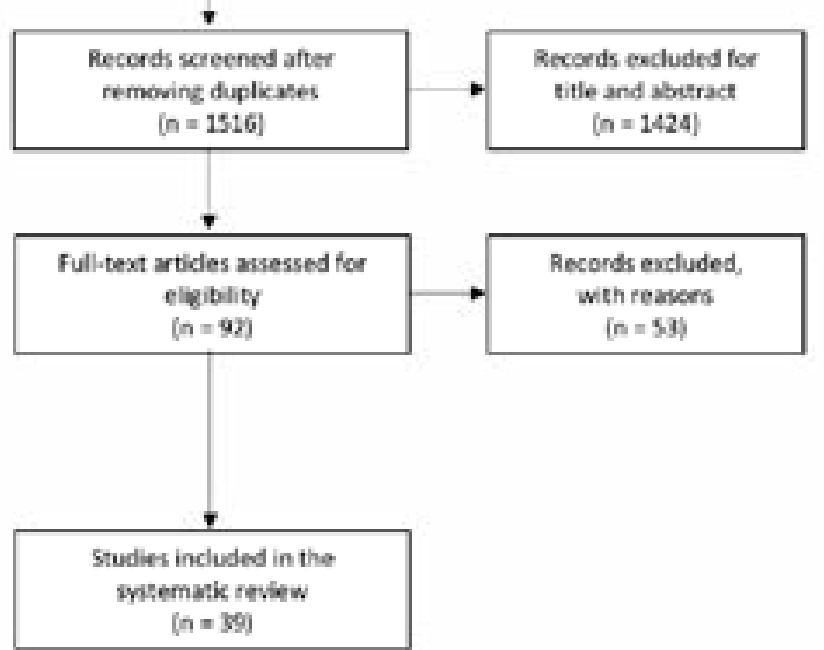

Figure 1 - Flow chart of search strategy and selection of articles.
Table 1 - List of included articles scored according to the PEDro scale.

\begin{tabular}{|c|c|c|c|c|}
\hline & $\begin{array}{l}\text { Selection } \\
(1-2-3-4)\end{array}$ & $\begin{array}{c}\text { Comparability } \\
(5-6-7)\end{array}$ & $\begin{array}{c}\text { Results } \\
(8-9-10-11)\end{array}$ & Total \\
\hline Oliveira et al. ${ }^{26}$ & \#-*-*-* & $0-0-0$ & *-****** & 7 \\
\hline Wernbom et al. ${ }^{20}$ & \#-*-*-* & $0-0-*$ & *-****** & 8 \\
\hline Brown et al. ${ }^{16}$ & $\#-0-0-*$ & $0-0-0$ & *-***** $_{-}$ & 5 \\
\hline Chatzinikolaou et al. ${ }^{17}$ & \#-*-*-* & $0-0-0$ & $x_{-} x_{-} x_{-} *$ & 7 \\
\hline Smilios et al. ${ }^{44}$ & $\#-0-0-*$ & $0-0-0$ & *-****** & 5 \\
\hline Walker et al. ${ }^{34}$ & $\#-0-0-*$ & $0-0-0$ & *-***** $_{-}$ & 5 \\
\hline Greco et al. ${ }^{27}$ & 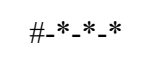 & $0-0-0$ & 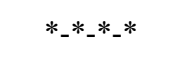 & 7 \\
\hline Izquierdo et al. ${ }^{33}$ & $\#-0-0-*$ & $0-0-0$ & $*_{--*}^{*} *_{-} *$ & 5 \\
\hline Sánchez-Medina et al. ${ }^{32}$ & $\#-0-0-*$ & $0-0-0$ & 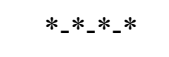 & 5 \\
\hline Buitrago et al. ${ }^{37}$ & \#-*-*-* & $*_{-0-0}$ & *-****** & 8 \\
\hline Hardee et al. ${ }^{35}$ & \#-****** & $*_{-0-0}$ & *-****** & 8 \\
\hline Paulo et al. ${ }^{45}$ & \#-*-**** & $*_{-0-0}$ & *-****** & 8 \\
\hline Walker et al. ${ }^{12}$ & 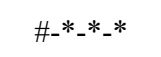 & $*_{-0-0}$ & *-****** & 8 \\
\hline Couto et al. "1 & 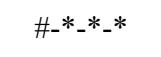 & $*_{-0-0}$ & *-****** & 8 \\
\hline Fernandez-Gonzalo et al. ${ }^{25}$ & $\#-0-0-*$ & $0-0-0$ & *-****** & 5 \\
\hline Okuno et al. ${ }^{21}$ & \#-*-**** & $*_{-0-0}$ & 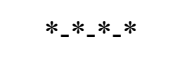 & 8 \\
\hline Pareja-Blanco et al. ${ }^{2}$ & \#-*-**** & $*_{-0-0}$ & 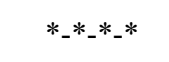 & 8 \\
\hline Rogatzki et al. ${ }^{46}$ & 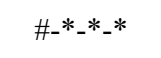 & $0-0-0$ & *-****** & 7 \\
\hline Silva et al. ${ }^{47}$ & $\#-0-0-*$ & $0-0-0$ & *-***** & 5 \\
\hline Ammar et al. ${ }^{48}$ & \#-*-**** & $0-0-0$ & *-****** & 7 \\
\hline Gadruni et al. ${ }^{24}$ & $\#-0-0-*$ & $0-0-0$ & *-****** & 5 \\
\hline González-Badillo et al. ${ }^{49}$ & \#-*-**** & $0-0-0$ & *-****** & 7 \\
\hline Nicholson et al. ${ }^{13}$ & \#-*-**** & $*_{-0-0}$ & 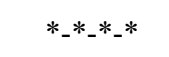 & 8 \\
\hline Ojeda et al. ${ }^{\prime}$ & $\#-0-0-*$ & $0-0-0$ & *-****** & 5 \\
\hline Poton et al. ${ }^{22}$ & 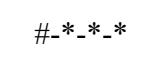 & $*_{-0-0}$ & 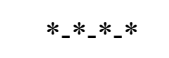 & 8 \\
\hline Raeder et al. ${ }^{39}$ & $\#-0-0-*$ & $0-0-0$ & *-****** & 5 \\
\hline Sabido et al. ${ }^{5}$ & 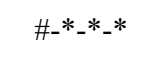 & $0-0-0$ & *-***** $_{-}$ & 7 \\
\hline Bartolomei et al. 50 & \#-****** & $0-0-0$ & *-****** & 7 \\
\hline de Almeida et al. ${ }^{23}$ & \#-****** & $0-0-0$ & *-****** & 7 \\
\hline Johnston et al. ${ }^{51}$ & \#-*-**** & $*_{-0-0}$ & *-****** & 8 \\
\hline Andreatta et al. ${ }^{52}$ & $\#-0-0-*$ & $0-0-0$ & *-****** & 5 \\
\hline Curty et al. ${ }^{53}$ & \#-*-**** & $0-0-0$ & *-****** & 7 \\
\hline dos Santos et al. s4 $^{54}$ & $\#-0-0-*$ & $0-0-0$ & *-****** & 5 \\
\hline Ojeda et al. ${ }^{29}$ & \#-0-0-* & $0-0-0$ & *-****** & 5 \\
\hline Miranda et al. ${ }^{55}$ & \#-****** ～～～ & $0-0-0$ & *-****** & 7 \\
\hline Párraga-Montilla et al. 56 & $\#-0-0-^{*}$ & $0-0-0$ & *-****** & 5 \\
\hline Sieljacks et al. ${ }^{57}$ & 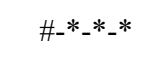 & ${ }^{*}-0-0$ & *-****** & 8 \\
\hline Wertheimer et al. ${ }^{19}$ & \#-****** ～～～ & $0-0-0$ & *-****** & 7 \\
\hline Tufano et al. 58 & \#-****** ～～～ & $*_{-0-0}$ & *-****** & 8 \\
\hline
\end{tabular}

Motriz, Rio Claro, v.26, Issue 3, 2020, el020006. 


\section{Results}

Selected studies

The electronic search identified 3468 articles, of which 1952 ere duplicated. The remaining 1516 articles were filtered by titles and abstracts, leaving 92 articles for full reading and anal-
ysis. After reviewing the 92 articles, 53 were removed, all for theeting the inclusion criteria. By not including articles after

a citation-oriented search, a total of 39 articles were obtained for a systematic review. These articles were stratified according to the protocol used. (i) plyometic training, (ii) Bodypump $\mathbb{B}$ training, (iii) occlusion training, (iv) variable resistance training, (v) conventional strength training, (vi) eccentric strenght training, (vii) rest times in strength training and (viii) concurrent training. At he end of the review, hhere was evidence from studies of physiological and biochemical responses related to strength of physiological and biochemical responses related to strength
training. Only those studies that related strength training to indicators of muscle fatigue are presented below (Table 2 and 3 ).

Table 2 - Characteristics of the participants in each study.

\begin{tabular}{|c|c|c|c|}
\hline Author & Number (M/F) & Age & Sample type \\
\hline Oliveira et al. ${ }^{26}$ & $0 / 15$ & $21.7 \pm 2.1$ & Not physically trained \\
\hline Wernbom et al. ${ }^{20}$ & $8 / 3$ & $20-39$ & Velocity and trained footballers \\
\hline Brown et al. ${ }^{16}$ & $10 / 10$ & $22.1 \pm 1.3$ & Recreative trained \\
\hline Chatzinikolaou et al. ${ }^{17}$ & 24/0 & $25.5 \pm 1.9$ & Physically healthy subjects \\
\hline Smilios et al. ${ }^{44}$ & $16 / 0$ & $20.7 \pm 1.1$ & Young people with recreational experience in strength \\
\hline Walker et al. ${ }^{34}$ & $10 / 0$ & $23.6 \pm 2.5$ & Recreative trained in strength \\
\hline Greco et al. ${ }^{27}$ & $0 / 19$ & $21.4 \pm 2.0$ & Sedentary \\
\hline Izquierdo et al. ${ }^{33}$ & $12 / 0$ & $33.0 \pm 4.4$ & Physically active subjects \\
\hline Sánchez-Medina et al. ${ }^{32}$ & $18 / 0$ & $25.6 \pm 3.4$ & Trained subjects \\
\hline Buitrago et al. ${ }^{37}$ & $10 / 0$ & $27.3 \pm 3.2$ & Students physical education with experience in strength \\
\hline Hardee et al. ${ }^{35}$ & $10 / 0$ & $23.6 \pm 0.37$ & Subjects trained in strength \\
\hline Paulo et al. 45 & $19 / 0$ & $25.7 \pm 4.4$ & Physically healthy young people \\
\hline Walker et al. ${ }^{12}$ & $13 / 0$ & $28.4 \pm 3.7$ & Physically active subjects with no experience in strength \\
\hline Couto et al. " & $32 / 0$ & $26.0 \pm 3.46$ & Subjects with experience in strength \\
\hline Fernandez-Gonzalo et al. 25 & $16 / 16$ & $23 \pm 1$ & Healthy and physically active subjects \\
\hline Okuno et al. ${ }^{21}$ & 9/0 & $24.0 \pm 2.9$ & Healthy subjects with experience in strength \\
\hline Pareja-Blanco et al. ${ }^{2}$ & $29 / 0$ & $23.3 \pm 3.2$ & Students of sports sciences with experience in strength \\
\hline Rogatzki et al. 46 & $6 / 0$ & $18-24$ & Teenagers \\
\hline Silva et al. ${ }^{47}$ & $11 / 0$ & $32 \pm 6$ & Trained cyclists \\
\hline Ammar et al. 48 & 9/0 & $21 \pm 0.5$ & Experienced weightlifters \\
\hline Gadruni et al. ${ }^{24}$ & $14 / 0$ & $22.64 \pm 1.49$ & Taekwondo athletes and sedentary subjects \\
\hline González-Badillo et al. ${ }^{99}$ & 9/0 & $23.3 \pm 3.9$ & Students of sports sciences with experience in strength \\
\hline Nicholson et al. ${ }^{13}$ & $34 / 0$ & $21.76 \pm 2.60$ & Trained subjects \\
\hline Ojeda et al. ${ }^{1}$ & $19 / 0$ & $24.8 \pm 5.3$ & Military pentathletes \\
\hline Poton et al. ${ }^{22}$ & $12 / 0$ & $23.4 \pm 3.8$ & Healthy and trained subjects \\
\hline Raeder et al. ${ }^{39}$ & 14/9 & $24.1 \pm 2.0$ & Athletes \\
\hline Sabido et al. ${ }^{5}$ & $17 / 0$ & $23.2 \pm 3.6$ & Subjects with experience in strength \\
\hline Bartolomei et al. 50 & $12 / 0$ & $24.5 \pm 4.2$ & Subjects with experience in strength \\
\hline de Almeida et al. ${ }^{23}$ & $10 / 0$ & $22.50 \pm 2.84$ & Subjects with experience in strength \\
\hline Johnston et al. ${ }^{51}$ & $15 / 0$ & $21 \pm 1$ & Rugby players \\
\hline Andreatta et al. ${ }^{52}$ & $10 / 10$ & $24 \pm 6$ & Healthy subjects with experience in strength \\
\hline Curty et al. ${ }^{53}$ & 9/0 & $26 \pm 1$ & Healthy subjects with experience in strength \\
\hline dos Santos et al. ${ }^{54}$ & $7 / 6$ & $29.5 \pm 6$ & Physically active subjects \\
\hline Ojeda et al. ${ }^{29}$ & $10 / 0$ & $28.5 \pm 4.8$ & Military athletes \\
\hline
\end{tabular}

$\begin{array}{lccl}\text { Miranda et al. } 55 & 0 / 15 & 25.7 \pm 4.7 & \text { Recreative trained } \\ \text { Párraga-Montilla et al. } 56 & 11 / 0 & 22.5 \pm 3.1 & \text { Subjects trained in strength } \\ \text { Sieljacks et al. } 57 & 14 / 0 & 23-27 & \text { Untrained youth } \\ \text { Wertheimer et al. } 19 & 20 / 0 & 22 \pm 1.80 & \text { Physically active subjects } \\ \text { Tufano et al. } 58 & 8 / 0 & 25.2 \pm 4.1 & \text { Subjects trained in strength }\end{array}$

Subjects trained in streng
Table 3 - Characteristics of strength training programs with muscle fatigue indicators.

\begin{tabular}{|c|c|c|c|c|c|c|c|}
\hline Author & Year & Objective & Variable & Treatment & $\begin{array}{c}\text { Results from } \\
\text { muscular } \\
\text { damage }\end{array}$ & Force results & Performance \\
\hline Oliveira et al. ${ }^{26}$ & 2009 & 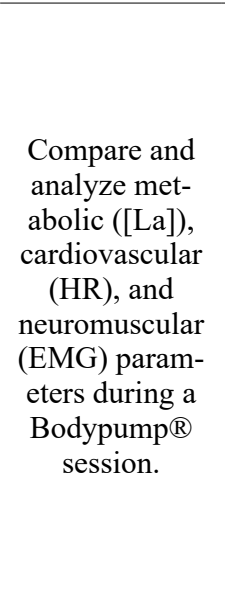 & $\begin{array}{c}\text { Exercises } \\
\text { proposed } \\
\text { by Body- } \\
\text { pump® }\end{array}$ & 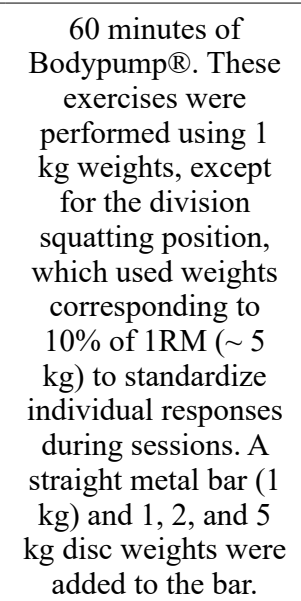 & $\begin{array}{c}\uparrow(\mathrm{p}<0.05) \\
{[\mathrm{La} \text { and } \mathrm{HR}} \\
\text { during the } \\
\text { session. There } \\
\text { was no signifi- } \\
\text { cant correlation } \\
\text { between EMG, } \\
\text { lactate, and HR } \\
\text { variables. }\end{array}$ & $\begin{array}{l}\text { 1RM and } \\
\text { CMJ were ns }\end{array}$ & $=$ \\
\hline Wernbom et al. ${ }^{20}$ & 2009 & $\begin{array}{l}\text { Investigate } \\
\text { whether there } \\
\text { was any } \\
\text { difference in } \\
\text { muscle activity } \\
\text { and endurance } \\
\text { during low-in- } \\
\text { tensity exercise } \\
\text { in dynamic } \\
\text { knee extension } \\
\text { performed up } \\
\text { to fatigue with } \\
\text { and without } \\
\text { occlusion. }\end{array}$ & $\begin{array}{c}\text { Dynamic } \\
\text { knee } \\
\text { extension } \\
\text { training } \\
\text { with and } \\
\text { without } \\
\text { occlusion }\end{array}$ & $\begin{array}{l}\text { Isotonic resistance } \\
\text { in knee extenders, } 4 \\
\text { sets of three repeti- } \\
\text { tions at } 85 \% \text { of } 1 \mathrm{RM} \\
\text { with } 4 \text { min rest inter- } \\
\text { vals between sets. }\end{array}$ & $\begin{array}{l}\text { RPE and acute } \\
\text { pain were ns be- } \\
\text { tween leg with } \\
\text { and without oc- } \\
\text { clusion. DOMS } \\
\text { increased (p } \\
<0.05 \text { in leg } \\
\text { without occlu- } \\
\text { sion after } 48 \\
\text { hours. }\end{array}$ & $\begin{array}{c}\text { Electrical } \\
\text { activity } \\
\text { between leg } \\
\text { with occlusion } \\
\text { and without } \\
\text { occlusion was } \\
\text { ns. }\end{array}$ & $=$ \\
\hline Brown et al. ${ }^{16}$ & 2010 & $\begin{array}{l}\text { Investigate } \\
\text { acuute changes } \\
\text { in O2, HR, and } \\
\text { blood [La] in a } \\
\text { deep plyo- } \\
\text { metric session } \\
\text { in men and } \\
\text { women. }\end{array}$ & $\begin{array}{l}\text { Deep } \\
\text { PD acute } \\
\text { session }\end{array}$ & $\begin{array}{l}\text { Resistance to } 30 \% \text { of } \\
1 \text { RM. Occlusion was } \\
\text { used at a pressure of } \\
100 \mathrm{~mm} \text { Hg just be- } \\
\text { fore the cuff exercise, } \\
\text { and this pressure was } \\
\text { maintained in the } \\
\text { occluded leg during } \\
\text { exercise, including } \\
\text { rest periods between } \\
\text { series. Subjects per- } \\
\text { formed as many rep- } \\
\text { etitions as possible } \\
\text { for a total of s series } \\
\text { for each leg. The rest } \\
\text { between each series } \\
\text { was } 45 \text { seconds for } \\
\text { both the nonoccluded } \\
\text { and occluded leg. }\end{array}$ & $\begin{array}{l}\uparrow(\mathrm{p}<0.05) \text { in } \\
{[\mathrm{La}], \mathrm{HR} \text { and }} \\
\mathrm{O} 2 \text { during the } \\
\text { session. }\end{array}$ & $\begin{array}{l}\text { SJ was ns; } \\
\text { however, } \\
\text { women pre- } \\
\text { sented } \downarrow \text { (p< } \\
0.05) \text { in jump- } \\
\text { ing height } \\
\text { compared to } \\
\text { post-test men. }\end{array}$ & $\begin{array}{c}=\text { in men, } \downarrow \text { in } \\
\text { women }\end{array}$ \\
\hline
\end{tabular}




\begin{tabular}{|c|c|c|c|c|c|c|c|}
\hline Chatzinikolaou et al. ${ }^{17}$ & 2010 & $\begin{array}{l}\text { Investigate } \\
\text { the temporal } \\
\text { course of } \\
\text { inflammatory, } \\
\text { hormonal, and } \\
\text { performance } \\
\text { marker chang- } \\
\text { es involved in } \\
\text { the inflamma- } \\
\text { tory response } \\
\text { during a } 5 \text {-day } \\
\text { recovery peri- } \\
\text { od following } \\
\text { an acute series } \\
\text { of plyometric } \\
\text { exercise }\end{array}$ & $\begin{array}{l}\text { Acute PD } \\
\text { session }\end{array}$ & $\begin{array}{l}8 \text { sets of } 10 \text { jumps } \\
\text { in-depth with both } \\
\text { feet of a box } 0.8 \\
m \text { high. When the } \\
\text { subjects reached the } \\
\text { ground with both } \\
\text { feet, they imme- } \\
\text { diately jumped as } \\
\text { high as possible and } \\
\text { touched a vertical } \\
\text { jump measurement } \\
\text { device; the subjects } \\
\text { turned and mounted } \\
\text { the jump box using } \\
3 \text { incremental steps } \\
\text { that were } 0.2 \mathrm{~m} \\
\text { higher than the pre- } \\
\text { vious one. Subjects } \\
\text { performed } 8 \text { series of } \\
10 \text { repetitions with } \\
3 \text { minutes of passive } \\
\text { recovery between } \\
\text { series. }\end{array}$ & 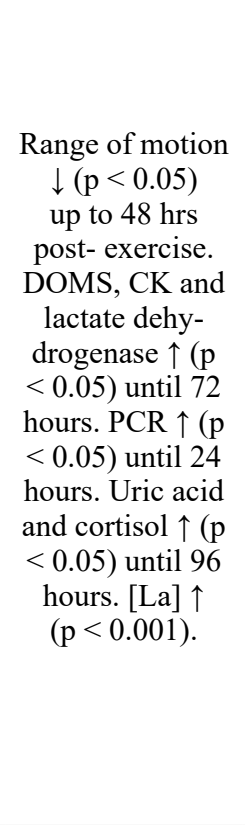 & $\begin{array}{c}\mathrm{CMJ} \text { and } \mathrm{SJ} \\
\downarrow(\mathrm{p}<0.05) \\
24 \text { hours after } \\
\mathrm{PD} \text { and } \downarrow \text { was } \\
\text { maintained up } \\
\text { to } 72 \text { hours. }\end{array}$ & $\downarrow$ \\
\hline Smilios et al. ${ }^{44}$ & 2010 & $\begin{array}{l}\text { Examine (a) } \\
\text { the mechanical } \\
\text { power and } \\
\text { activity of } \\
\text { EMG during } \\
\text { a moderately } \\
\text { loaded muscu- } \\
\text { lar endurance } \\
\text { session and (b) } \\
\text { the maximum } \\
\text { mechanics out- } \\
\text { put power and } \\
\text { EMG activity } \\
\text { using a light } \\
\text { load and then a } \\
\text { heavy load }\end{array}$ & $\begin{array}{l}\text { Medium, } \\
\text { light and } \\
\text { heavy } \\
\text { load } \\
\text { endurance } \\
\text { exercise }\end{array}$ & $\begin{array}{l}50 \text { jumps over } 50 \\
\text { cm obstacles }(5 \text { sets } \\
\text { of } 10 \text { repetitions) } \\
\text { and } 50 \text { jumps with } \\
\text { plyometric box drop } \\
50 \mathrm{~cm} \text { (5 sets of } 10 \\
\text { repetitions). There } \\
\text { were } 2 \text { and } 5 \text { minutes } \\
\text { of rest between } \\
\text { sets and exercises, } \\
\text { respectively. }\end{array}$ & $\begin{array}{c}{[\mathrm{La}] \uparrow(\mathrm{p}<} \\
0.05) .\end{array}$ & $\begin{array}{c}\text { Loads used } \\
\text { in third and } \\
\text { fourth series } \downarrow \\
\text { ( }<0.05 \text { ) ver- } \\
\text { sus first and } \\
\text { second series. } \\
\text { Production of } \\
\text { force } \downarrow \text { ( }<< \\
0.05 \text { ) during } \\
\text { last } 2 \text { series. } \\
\text { Average speed } \\
\text { of each series } \\
\text { was ns. }\end{array}$ & $\downarrow$ \\
\hline Walker et al. ${ }^{34}$ & 2010 & $\begin{array}{l}\text { Evaluate acute } \\
\text { and endocrine } \\
\text { neuromuscu- } \\
\text { lar responses } \\
\text { during a con- } \\
\text { trast loading } \\
\text { protocol }\end{array}$ & $\begin{array}{l}\text { Contrast } \\
\text { training }\end{array}$ & $\begin{array}{l}\text { The lifting protocol } \\
\text { was } 10 \times 5 \text {-speed } \\
\text { squats at } 70 \% \text { of the } \\
\text { mass of the system } \\
\text { (RM) with rest } \\
\text { intervals of } 2 \text { minutes } \\
\text { between sets. }\end{array}$ & {$[\mathrm{La}]=$} & $\begin{array}{l}\uparrow(\mathrm{p}<0.05) \\
\text { on SJ jump } \\
\text { and maximum } \\
\text { isometric } \\
\text { force. }\end{array}$ & $\uparrow$ \\
\hline Greco et al. ${ }^{27}$ & 2011 & $\begin{array}{l}\text { To assess the } \\
\text { effects of } 12 \\
\text { weeks of the } \\
\text { Bodypump® } \\
\text { training } \\
\text { program on } \\
\text { neuromuscular } \\
\text { aspects and } \\
\text { metabolic } \\
\text { variables, such } \\
\text { as HR and } \\
\text { lactate. }\end{array}$ & $\begin{array}{l}\text { Body- } \\
\text { pump® }\end{array}$ & 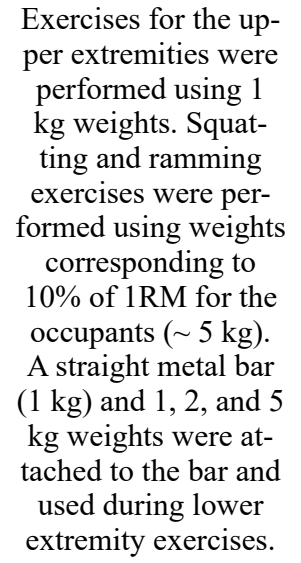 & $\begin{array}{l}\text { [La] and HR } \\
\text { were ns. }\end{array}$ & $\begin{array}{l}\uparrow(p<0.05) \\
\text { max. force }\end{array}$ & $\uparrow$ \\
\hline
\end{tabular}

\begin{tabular}{|c|c|c|c|c|c|c|c|}
\hline Izquierdo et al. ${ }^{33}$ & 2011 & $\begin{array}{l}\text { Effects of } \\
\text { heavy-duty } \\
\text { training and } \\
\text { its relationship } \\
\text { between power } \\
\text { loss and EMG } \\
\text { rates and blood } \\
\text { metabolite } \\
\text { concentrations } \\
\text { on exercise-in- } \\
\text { duced dynamic } \\
\text { fatigue }\end{array}$ & $\begin{array}{l}\text { Strength } \\
\text { training }\end{array}$ & $\begin{array}{l}\text { Five series, with the } \\
\text { load corresponding } \\
\text { to } 10 \mathrm{RM} \text { on the } \\
\text { leg press with } 120 \mathrm{~s} \\
\text { of rest between the } \\
\text { series. After train- } \\
\text { ing, each subject } \\
\text { performed an acute } \\
\text { load resistance pro- } \\
\text { tocol with the same } \\
\text { relative load (10 RM) } \\
\text { as in the pre-workout } \\
\text { test protocols. }\end{array}$ & $\begin{array}{l}\text { [La], ammonia, } \\
\text { and uric acid } \uparrow \\
\quad(p<0.05)\end{array}$ & $\begin{array}{l}\text { Maximum } \\
\text { power loss } \\
(p<0.05)\end{array}$ & $\downarrow$ \\
\hline Sánchez-Medina et al. ${ }^{32}$ & 2011 & $\begin{array}{l}\text { Analyze the } \\
\text { acute mechan- } \\
\text { ical and meta- } \\
\text { bolic responses } \\
\text { to resistance } \\
\text { exerise proto- } \\
\text { cols that differ } \\
\text { in the number } \\
\text { of repetitions } \\
\text { performed in } \\
\text { each series } \\
\text { from the } \\
\text { expected maxi- } \\
\text { mum number. }\end{array}$ & $\begin{array}{l}\text { Bench } \\
\text { press and/ } \\
\text { or squat } \\
\text { exercises }\end{array}$ & $\begin{array}{l}\text { Subjects performed } \\
50 \text { jumps at the } \\
\text { maximum continuous } \\
\text { intensity at approx- } \\
\text { imately a } 90-\text { degree } \\
\text { angle at the knees, } \\
\text { and after } 60 \text { minutes } \\
\text { of rest, performed the } \\
\text { second series. }\end{array}$ & $\begin{array}{l}\text { [La] and ammo- } \\
\text { nia } \uparrow(p<0.05)\end{array}$ & $\begin{array}{c}\downarrow(\mathrm{p}<0.05) \\
\text { average speed } \\
\text { of bar and } \\
\text { CMJ move- } \\
\text { ment }\end{array}$ & $\downarrow$ \\
\hline Buitrago et al. ${ }^{37}$ & 2012 & $\begin{array}{l}\text { Examine acute } \\
\text { physiological } \\
\text { and metabolic } \\
\text { responses to a } \\
\text { comprehensive } \\
\text { bench press } \\
\text { exercise of } 4 \\
\text { exercise modes } \\
\text { with different } \\
\text { speeds and dif- } \\
\text { ferent external } \\
\text { loads. }\end{array}$ & $\begin{array}{c}\text { Press } \\
\text { banking }\end{array}$ & $\begin{array}{l}4 \text { sets of } 20 \text { repeti- } \\
\text { tions with an initial } \\
\text { load of } 50 \% \text { of } 1 \text { 1RM } \\
\text { and } 2 \text { minutes rest in } \\
\text { the squat exercise. } \\
\text { In addition, sub- } \\
\text { jects performed } 4 \\
\text { repetitions with loads } \\
\text { of } 40 \% \text { and } 80 \% \text { of } \\
1 \text { RM before, imme- } \\
\text { diately after, and } 30 \\
\text { minutes after the end } \\
\text { of the session. }\end{array}$ & $\begin{array}{l}{[\mathrm{La}] \uparrow(\mathrm{p}<0.01)} \\
\text { at high, medium } \\
\text { and low loads }\end{array}$ & $\begin{array}{l}\downarrow(\mathrm{p}<0.01) \\
\text { number of } \\
\text { repetitions }\end{array}$ & $\downarrow$ \\
\hline Hardee et al. ${ }^{35}$ & 2012 & $\begin{array}{l}\text { Examine the } \\
\text { effects of rest } \\
\text { between repe- } \\
\text { titions on RPE } \\
\text { ratings in the } \\
\text { power clean } \\
\text { exercise. }\end{array}$ & $\begin{array}{l}\text { Power } \\
\text { clean }\end{array}$ & $\begin{array}{l}4 \text { sets of squats ( } 3 \% \\
\text { to } 80 \% \text { of } 1 \mathrm{RM}) \\
\text { interspersed with } 4 \\
\text { sets of SJ (three rep- } \\
\text { etitions). A 3-minutee } \\
\text { break was allowed } \\
\text { between sets. }\end{array}$ & $\begin{array}{c}\operatorname{RPE} \uparrow(\mathrm{p}< \\
0.05)\end{array}$ & $\begin{array}{l}\downarrow(p<0.05) \\
\text { on the output } \\
\text { power }\end{array}$ & $\downarrow$ \\
\hline Paulo et al. ${ }^{45}$ & 2012 & $\begin{array}{l}\text { Evaluate the } \\
\text { influence of } \\
\text { different rest } \\
\text { intervals and } \\
\text { the number } \\
\text { of repetitions } \\
\text { per set on the } \\
\text { production of } \\
\text { muscle power } \\
\text { in the squat ex- } \\
\text { ercise between } \\
\text { exercises and } \\
\text { the rest ratio. }\end{array}$ & $\begin{array}{l}\text { Squatting } \\
\text { force } \\
\text { work }\end{array}$ & $\begin{array}{l}\text { MVC force and then } \\
\text { the performance of } \\
\text { a resistance exercise } \\
\text { protocol composes of } \\
\text { three series of bicep } \\
\text { curls at } 40 \% \text { MVC } \\
\text { with } 1 \text { minute or } 3 \\
\text { minutes time interval } \\
\text { between series. }\end{array}$ & $\begin{array}{c}\text { [La] } \uparrow(p<0.05) \\
\text { in (SSSI and } \\
\text { LSLI). SSLI } \downarrow \\
\text { (p }<0.05) \text { in } \\
\text { [La] when com- } \\
\text { pared to LSLI }\end{array}$ & $\begin{array}{l}\text { Average pow- } \\
\text { er } \uparrow(\mathrm{p}<0.05) \\
\text { in SSLI }\end{array}$ & $\begin{array}{l}\text { An } \uparrow \text { in the } \\
\text { intensity } \\
\text { and volume } \\
\text { of training } \\
\text { produces } \downarrow \\
\text { performance }\end{array}$ \\
\hline
\end{tabular}




\begin{tabular}{|c|c|c|c|c|c|c|c|}
\hline Walker et al. ${ }^{12}$ & 2012 & $\begin{array}{l}\text { To compare } \\
\text { acute neu- } \\
\text { romuscular } \\
\text { fatigue during } \\
\text { maximum } \\
\text { dynamic force } \\
\text { and hypertro- } \\
\text { phic loads. }\end{array}$ & $\begin{array}{l}\text { Exer- } \\
\text { cise of } \\
\text { force. } 15 \\
\text { series of } 1 \\
\text { maximum } \\
\text { repetition } \\
\text { (MAX) } \\
\text { and 5 se- } \\
\text { ries of } 10 \\
\text { maximum } \\
\text { repe- } \\
\text { titions } \\
\text { (HYP). }\end{array}$ & $\begin{array}{l}\text { Bodypump®, the } \\
\text { initial workload } \\
\text { (kg) used for squats } \\
\text { and onslaughts was } \\
10 \% \text { of } 1 \text { RM squats. } \\
\text { Upper limb and trunk } \\
\text { exercises were per- } \\
\text { formed at a workload } \\
\text { of } 2 \mathrm{~kg} \text { for weights } \\
\text { or } 1 \mathrm{~kg} \text { for free } \\
\text { weights. Workload } \\
\text { increases for squats } \\
\text { and onslaughts were } \\
5 \% \text { every } 2 \text { weees ( } 4 \\
\text { sessions). }\end{array}$ & $\begin{array}{c}{[\mathrm{La}] \uparrow(\mathrm{p}<0.01)} \\
\text { in hypertrophy } \\
\text { group }\end{array}$ & $\begin{array}{l}\text { Concentric } \\
\text { load during } \\
\text { maximum } \\
\text { force } \downarrow \text { ( }<< \\
0.05) \text {, Con- } \\
\text { centric force } \\
\text { and maximum } \\
\text { isometric } \downarrow \\
(p<0.001) \text { in } \\
\text { both groups. }\end{array}$ & $\begin{array}{l}\text { Hypertrophy } \\
\text { work produc- } \\
\text { es } \downarrow \text { perfor- } \\
\text { mance }\end{array}$ \\
\hline Couto et al. "11 & 2013 & $\begin{array}{l}\text { To verify the } \\
\text { acute effects of } \\
\text { the application } \\
\text { of local vibra- } \\
\text { tion in the upper } \\
\text { extremities } \\
\text { during resis- } \\
\text { tance training } \\
\text { on the number } \\
\text { of maximum } \\
\text { repetitions } \\
\text { and metabolic } \\
\text { and hormonal } \\
\text { responses. }\end{array}$ & $\begin{array}{l}\text { Vibration } \\
\text { strength } \\
\text { training } \\
\text { session } \\
\text { and } \\
\text { non-vi- } \\
\text { bration } \\
\text { strength } \\
\text { training }\end{array}$ & $\begin{array}{l}5 \text { sets of } 10 \text { repeti- } \\
\text { tions in the leg press, } \\
\text { with } 2 \text { minutes rest } \\
\text { between sets. }\end{array}$ & $\begin{array}{l}\text { [La], testos- } \\
\text { terone and } \\
\text { cortisol } \uparrow(p< \\
0.05) \text { after both } \\
\text { interventions. } \\
\text { However [La] } \\
\text { and testosterone } \\
\uparrow \uparrow(p<0.05) \\
\text { compared to the } \\
\text { non-vibration } \\
\text { group. CK and } \\
\text { urea were ns in } \\
\text { both groups. }\end{array}$ & $\begin{array}{l}\text { Number of } \\
\text { repetitions } \downarrow \\
(\mathrm{p}<0.05) \text { in } \\
\text { both groups }\end{array}$ & $\downarrow$ \\
\hline Fernandez-Gonzalo et al. ${ }^{25}$ & 2014 & $\begin{array}{l}\text { To evaluate } \\
\text { markers of } \\
\text { muscle onagage } \\
\text { and training } \\
\text { adatatations to } \\
\text { eccentric over- } \\
\text { load endur- } \\
\text { ance exercise } \\
\text { in men and } \\
\text { women. }\end{array}$ & $\begin{array}{l}\text { Supine } \\
\text { squatting } \\
\text { training } \\
\text { position }\end{array}$ & $\begin{array}{l}\text { Repetitions carried } \\
\text { out in each series } \\
\text { with respect to the } \\
\text { maximum number } \\
\text { foreseen. }\end{array}$ & $\begin{array}{l}\text { The [La], was } \\
\text { greater after the } \\
\text { first training } \\
\text { session (p }< \\
0.05) \text {. C } \uparrow \text { (P } \\
<0.001) \text { in men } \\
\text { after the first } \\
\text { session. In both } \\
\text { sexes, CK and } \\
\text { [La] remained at } \\
\text { baseline in both } \\
\text { groups after the } \\
\text { last session. }\end{array}$ & 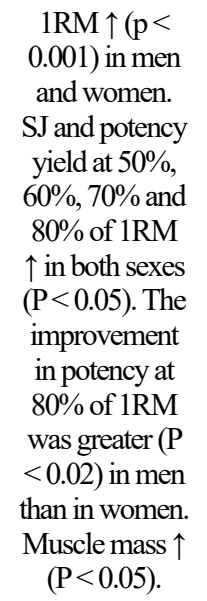 & $\uparrow$ \\
\hline Okuno et al. ${ }^{21}$ & 2014 & $\begin{array}{l}\text { To investigate } \\
\text { the variabil- } \\
\text { ity of HR } \\
\text { after resistance } \\
\text { training with } \\
\text { and without } \\
\text { occlusion. }\end{array}$ & $\begin{array}{c}\text { Leg } \\
\text { presses } \\
\text { with and } \\
\text { without } \\
\text { occlusion }\end{array}$ & $\begin{array}{l}3 \text { experimental } \\
\text { sessions on different } \\
\text { days, separated by } \\
\text { at least } 72 \text { hours and } \\
\text { a maximum of } 120 \\
\text { hours: (a) } 5 \text { series of } \\
\text { leg press exercises in } \\
80 \% \text { of } 1 \mathrm{RM} \text { without } \\
\text { vascular occlusion } \\
\text { (HI), (b) } 5 \text { series of } \\
\text { leg press exercises } \\
\text { at } 40 \% \text { of } 1 \mathrm{RM} \text { with } \\
\text { vascular occlusion } \\
\text { (IOL), and (c) } 5 \\
\text { series of leg press } \\
\text { exercises at } 40 \% \text { of } \\
1 \mathrm{RM} \text { without vascu- } \\
\text { lar occlusion (LI) of } \\
\text { each leg. }\end{array}$ & $\begin{array}{l}\mathrm{HI}, \mathrm{HR} \text { and }[\mathrm{La}] \\
\uparrow(\mathrm{p}<0.05), \\
\text { after exercise by } \\
\text { over LI and IOL }\end{array}$ & $\begin{array}{l}\text { Reduced re- } \\
\text { covery in HI }\end{array}$ & $\downarrow$ in $\mathrm{HI}$ \\
\hline
\end{tabular}

\begin{tabular}{|c|c|c|c|c|c|c|c|}
\hline Pareja-Blanco et al. ${ }^{2}$ & 2014 & $\begin{array}{l}\text { To compare the } \\
\text { effect of } 2 \text { dif- } \\
\text { ferent isomet- } \\
\text { ric resistance } \\
\text { training inter-er- } \\
\text { ventions on } \\
\text { strenghth gains } \\
\text { and selected } \\
\text { neuromusuluar } \\
\text { performance } \\
\text { measures using } \\
\text { movement } \\
\text { speed as an } \\
\text { independent } \\
\text { variable. }\end{array}$ & $\begin{array}{l}\text { Strength } \\
\text { training }\end{array}$ & 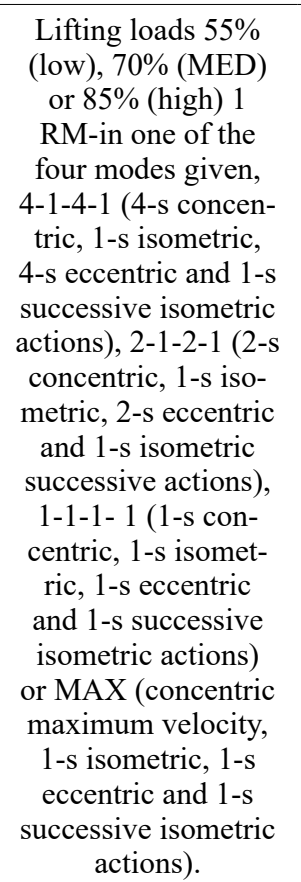 & $\begin{array}{c}{[\mathrm{La}] \text { and am- }} \\
\text { monia } \uparrow(\mathrm{p}< \\
0.05) \text { in MaxV } \\
\text { as compared to } \\
\text { HalfV }\end{array}$ & $\begin{array}{l}\mathrm{CMJ} \text { and } \\
\text { maximum } \\
\text { concentric } \\
\text { speed } \uparrow(\mathrm{p} \\
<0.001) \text { in } \\
\text { MaxV as } \\
\text { compared to } \\
\text { HalfV }\end{array}$ & $\uparrow$ \\
\hline Rogatzki et al. ${ }^{46}$ & 2014 & $\begin{array}{l}\text { Study II aimed } \\
\text { to describe } \\
\text { acute and } \\
\text { mechanical } \\
\text { metabolic re- } \\
\text { sponses to the } \\
\text { type of resis- } \\
\text { tance exercise } \\
\text { protocolols used } \\
\text { in Study I. }\end{array}$ & $\begin{array}{l}\text { Squat } \\
\text { with over- } \\
\text { load }\end{array}$ & 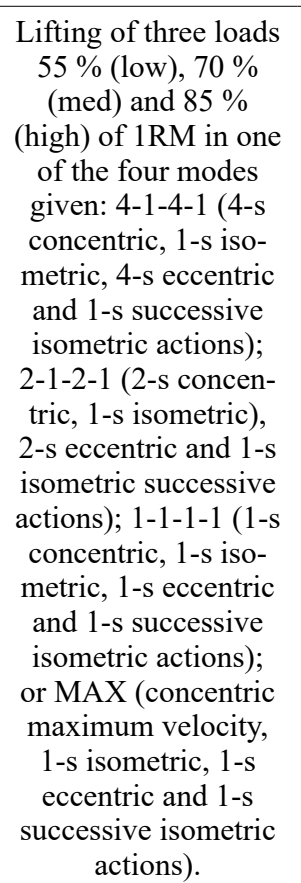 & $\begin{array}{c}{[\mathrm{La}] \uparrow(\mathrm{p}<} \\
0.005) \text { in muscle } \\
\text { endurance. } \uparrow(\mathrm{p} \\
<0.05) \text { plasma } \\
\text { ammonium by } \\
\text { over hypertro- } \\
\text { phy and strength } \\
\text { group. }\end{array}$ & $\begin{array}{l}\downarrow(\mathrm{p}<0.05) \text { in } \\
\text { time to com- } \\
\text { plete the } 20 \\
\text { km counter- } \\
\text { clockwise ex- } \\
\text { ercise. } \uparrow(\mathrm{p}< \\
0.01) \text { cycling } \\
\text { economy. }\end{array}$ & $\begin{array}{l}\downarrow \text { in muscle } \\
\text { endurance } \\
\text { group }\end{array}$ \\
\hline Silva et al. ${ }^{47}$ & 2014 & $\begin{array}{l}\text { To determine } \\
\text { the metabolic } \\
\text { response of } \\
\text { resistance } \\
\text { exercise in } \\
\text { overloaded } \\
\text { squats with dif- } \\
\text { ferent training } \\
\text { protocols. }\end{array}$ & Leg press & $\begin{array}{l}\text { Muscle resistance } \\
\text { performed in } 2 \text { series } \\
\text { of } 20 \text { repetitions at } \\
53 \% \text { of } 1 \text { RM with } 45 \\
\text { sof rest between the } \\
\text { series. Hypertrophy } \\
\text { training consisting } \\
\text { of } 3 \text { series of } 10 \\
\text { repeptitions at } 70 \% \\
\text { of } 12 M \text { with } 120 \mathrm{~s} \\
\text { of rest between the } \\
\text { series. For strength, } \\
\text { the trainings were } 5 \\
\text { series of } 5 \text { repetitions } \\
\text { at } 85 \% \text { of } 18 \text { M with } \\
180 \mathrm{~s} \text { o r rest between } \\
\text { the series. }\end{array}$ & $\begin{array}{l}\text { [The] and RPE } \\
\text { were ns }\end{array}$ & $\begin{array}{l}\text { Total load } \\
\text { volume } \uparrow \text { (P } \\
<0.001 \text { ) in } \\
\text { the afternoon } \\
\text { as compared } \\
\text { with the } \\
\text { morning and } \\
\text { evening. }\end{array}$ & $\uparrow$ \\
\hline
\end{tabular}




\begin{tabular}{|c|c|c|c|c|c|c|c|}
\hline Ammar et al. ${ }^{48}$ & 2015 & $\begin{array}{l}\text { Check whether } \\
\text { a pre-test } 5 \mathrm{RM} \\
\text { strength exer- } \\
\text { cise would im- } \\
\text { prove cycling } \\
\text { performance } \\
\text { during a 20 } \\
\text { km (TT20 km) } \\
\text { cycling event. }\end{array}$ & $\begin{array}{l}\text { Olympic } \\
\text { weight- } \\
\text { lifting at } \\
\text { different } \\
\text { times } \\
\text { of ay } \\
\text { (morning, } \\
\text { afternoon, } \\
\text { or eve- } \\
\text { ning) }\end{array}$ & $\begin{array}{l}\text { Program that } \\
\text { involved a rapid } \\
\text { gradual increase in } \\
\text { the number of jumps, } \\
\text { drop height, and } \\
\text { depth of squat and } \\
\text { weight addition. }\end{array}$ & $\begin{array}{l}\mathrm{RPE} \uparrow(\mathrm{P}<0.01) \\
\text { in the morming and } \\
\text { evening. Lactate } \\
\text { dehydrogenase } \\
\uparrow(\mathrm{P}<0.01) \text { in } \\
\text { the morning and } \\
\text { evening. CK } \uparrow(\mathrm{P} \\
<0.05) \text { at three } \\
\text { hours of the day. } \\
\text { Alanine amino- } \\
\text { transferase, gam- } \\
\text { ma-glutamyl, and } \\
\text { alkaline phoshhate } \\
\uparrow(\mathrm{P}<0.001) \text { in } \\
\text { the morning. }\end{array}$ & Not measured & $\begin{array}{l}\uparrow \text { in the after- } \\
\text { noon and } \downarrow \text { in } \\
\text { the morning } \\
\text { and evening }\end{array}$ \\
\hline Gadruni et al. ${ }^{24}$ & 2015 & $\begin{array}{l}\text { Investigate the } \\
\text { performance } \\
\text { of an Olympic } \\
\text { weightlift- } \\
\text { ing training } \\
\text { session three } \\
\text { times a day on } \\
\text { performance } \\
\text { related to } \\
\text { biochemical } \\
\text { responses. }\end{array}$ & $\begin{array}{l}\text { Elastic } \\
\text { exercises } \\
\text { with pro- } \\
\text { gressive } \\
\text { resistance }\end{array}$ & 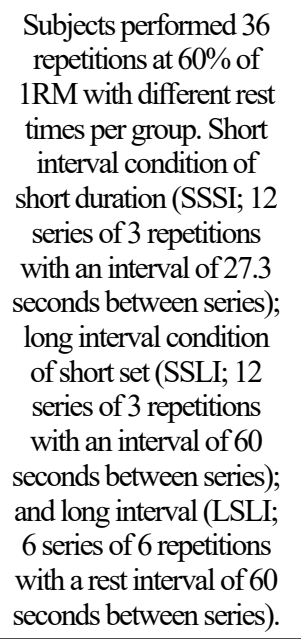 & $\begin{array}{l}\text { DOMS and RPE } \\
\uparrow(\mathrm{P}<0.05) \\
\uparrow(\mathrm{P}<0.05) \\
\text { CK, LDH, LL-6 } \\
\text { and PCR in } \\
\text { sedentary and } \\
\text { athletes. }\end{array}$ & $\begin{array}{c}\text { Group to } \\
\text { failure, } \downarrow \text { ( }<< \\
0.05) \text { CRGA } \\
\text { speed and } \\
\text { CMJ }\end{array}$ & $\downarrow$ \\
\hline González-Badillo et al. ${ }^{49}$ & 2016 & $\begin{array}{l}\text { Investigate } \\
\text { the effect of } \\
\text { acute cycles } \\
\text { of progressive } \\
\text { rubber band } \\
\text { exercises on } \\
\text { muscle damage } \\
\text { and inflamma- } \\
\text { tory responses } \\
\text { in Taekwondo } \\
\text { athletes. }\end{array}$ & $\begin{array}{c}\text { Bench } \\
\text { press and } \\
\text { squat with } \\
\text { overload }\end{array}$ & $\begin{array}{l}\text { Two leg press loads, } \\
\text { separated by one } \\
\text { week, consisting of } \\
15 \text { sets of } 1 \text { max- } \\
\text { imum repetition } \\
\text { (MAX) and } 5 \text { sets } \\
\text { of } 10 \text { maximum } \\
\text { repetitions. }\end{array}$ & $\begin{array}{c}{[\mathrm{La}] \uparrow(\mathrm{p}<0.05)} \\
\text { In both groups. } \\
\mathrm{CK} \text { and cortisol } \\
\uparrow(\mathrm{p}<0.05) \\
\text { in the group } \\
\text { with maximum } \\
\text { repetitions until } \\
\text { failure }\end{array}$ & $\begin{array}{l}1 \mathrm{RM} \uparrow(\mathrm{P}< \\
0.001) \text { in each } \\
\text { group }\end{array}$ & $\begin{array}{c}\text { Higher vol- } \\
\text { ume versions } \\
\downarrow \text { perfor- } \\
\text { mance }\end{array}$ \\
\hline Nicholson et al. ${ }^{13}$ & 2016 & $\begin{array}{l}\text { Analyze time } \\
\text { course of } \\
\text { recovery after } \\
2 \text { protocols } \\
\text { of resistance } \\
\text { exercises that } \\
\text { differ in the } \\
\text { level of effort: } \\
\text { maximum } \\
\text { (until failure) } \\
\text { versus half } \\
\text { the maximum } \\
\text { number of } \\
\text { repetitions per } \\
\text { series. }\end{array}$ & $\begin{array}{l}\text { Squat } \\
\text { with over- } \\
\text { load in } \\
\text { maximum } \\
\text { strength } \\
\text { mode, hy- } \\
\text { pertrophy, } \\
\text { or group } \\
\text { with more } \\
\text { rest, or } \\
\text { another } \\
\text { group } \\
\text { with less } \\
\text { volume } \\
\text { and total } \\
\text { rest. }\end{array}$ & $\begin{array}{l}\text { Conventional resistance } \\
\text { training session and } \\
\text { a resistance training } \\
\text { session with local } \\
\text { vibration. In both inter- } \\
\text { ventions, the volunteers } \\
\text { performeded } 4 \text { series with } \\
\text { the greatest possible } \\
\text { number of repetitions of } \\
\text { the exercisis that could } \\
\text { be deployed at } 55 \% \text { of } \\
\text { the maximum voluntary } \\
\text { contraction. During } \\
\text { the vibration resistance } \\
\text { training intervention the } \\
\text { vibration was applied } \\
\text { locally (20 Hz and } 12 \\
\text { mm). During conven- } \\
\text { tional resistance training, } \\
\text { volunteers performed } \\
\text { the same procedures } \\
\text { without vibration. }\end{array}$ & $\begin{array}{c}\text { Maximum } \\
\text { strength and hy- } \\
\text { pertrophy train- } \\
\text { ing [La] } \uparrow(\mathrm{p} \\
<0.001) ; \mathrm{RPE} \\
\uparrow(\mathrm{p}<0.05) \text { in } \\
\text { hypertrophy } \\
\text { protocol }\end{array}$ & $\begin{array}{c}\text { The Vmax, } \\
\text { Vpro, and } \\
\text { Pmax were ns. } \\
\text { La Ppro } \downarrow(\mathrm{p}= \\
0.002) .\end{array}$ & $\uparrow$ \\
\hline
\end{tabular}

\begin{tabular}{|c|c|c|c|c|c|c|c|}
\hline Ojeda et al. ${ }^{1}$ & 2016 & $\begin{array}{l}\text { Determine the } \\
\text { acute effect } \\
\text { of Complex } \\
\text { Training on } \\
\text { bench press on } \\
\text { grenade throw- } \\
\text { ing velocity } \\
\text { on military } \\
\text { pentathletes. }\end{array}$ & $\begin{array}{c}\text { Proto- } \\
\text { col of } \\
\text { complex } \\
\text { training } \\
\text { in bench } \\
\text { press }\end{array}$ & $\begin{array}{c}4 \text { sets of } 5 \text { repetitions } \\
\text { at } 30 \% \text { one Rep- } \\
\text { etition Maximum } \\
\text { (1RM) }+4 \text { repeti- } \\
\text { tions at } 60 \% \text { RMM } \\
+3 \text { grenade throws } \\
\text { with a } 15 \text {-second } \\
\text { rest. }\end{array}$ & $\begin{array}{c}{[\mathrm{La}] \uparrow(\mathrm{p}=} \\
0.001)\end{array}$ & Not measured & $\downarrow$ \\
\hline Poton et al. ${ }^{22}$ & 2016 & $\begin{array}{l}\text { To determine } \\
\text { the acute effect } \\
\text { of a protocol } \\
\text { of complex } \\
\text { training in } \\
\text { press banking } \\
\text { on the speed } \\
\text { of the launch } \\
\text { of the grenade } \\
\text { in military } \\
\text { pentathletes. }\end{array}$ & $\begin{array}{l}\text { Exercise } \\
\text { of force in } \\
\text { extension } \\
\text { of the } \\
\text { knee with } \\
\text { or without } \\
\text { restriction } \\
\text { of blood } \\
\text { flow. }\end{array}$ & $\begin{array}{c}\text { (a) } 5 \text { series of leg } \\
\text { press exercises at } \\
80 \% \text { of } 1 \text { RM without } \\
\text { vascular occlusion } \\
\text { (HI), (b) } 5 \text { series of } \\
\text { leg press exercises } \\
\text { at } 40 \% \text { of } 1 \text { RM with } \\
\text { vascular occlusion } \\
\text { (IOL), and (c) } 5 \\
\text { series of leg press } \\
\text { exercises at } 40 \% \text { of } \\
1 \text { RM without vascu- } \\
\text { lar occlusion (LI). }\end{array}$ & $\begin{array}{c}\text { HI, HR and } \\
\text { diastolic blood } \\
\text { pressure } \uparrow(\mathrm{P}< \\
0.05) \text {. [La] } \uparrow \\
(\mathrm{p}<0.05) \text { in } \\
\text { LI-BFR and } \\
\text { HI. RPE } \uparrow(\mathrm{p}< \\
\text { 0.05) in LI-BFR }\end{array}$ & $\underset{0.05)}{\operatorname{IRM} \downarrow(\mathrm{p})}$ & $\downarrow$ \\
\hline Raeder et al. ${ }^{39}$ & 2016 & $\begin{array}{l}\text { To compare } \\
\text { the hemody- } \\
\text { namic response } \\
\text { during resis- } \\
\text { tance exercise } \\
\text { to HI, LL, and } \\
\text { LI-BFR in } \\
\text { healthy sub- } \\
\text { jects. }\end{array}$ & $\begin{array}{l}\text { 6-day } \\
\text { intensive } \\
\text { strength } \\
\text { training }\end{array}$ & $\begin{array}{l}\text { Subjects trained } \\
\text { twice a day, in the } \\
\text { morning }(9 \mathrm{AM}) \\
\text { and the afternoon }(\sim 3 \\
\text { PM), on } 6 \text { consec- } \\
\text { utive days. They } \\
\text { performed multiple } \\
\text { resistance combined } \\
\text { with maximum } \\
\text { eccentric strength } \\
\text { exercises, focus- } \\
\text { ing mainly on the } \\
\text { training of the lower } \\
\text { extremities. }\end{array}$ & $\begin{array}{c}\text { DOMS, per- } \\
\text { ceived recovery } \\
\text { and stress } \uparrow(\mathrm{p}< \\
0.05 \text { < } \\
0.0 \mathrm{p}(\mathrm{p}< \\
0.05) .\end{array}$ & $\begin{array}{c}\text { All protocols } \\
\text { caused } \downarrow \text { ( }< \\
0.05 \text { at peak } \\
\text { speed }\end{array}$ & $\downarrow$ \\
\hline Sabido et al. ${ }^{5}$ & 2016 & $\begin{array}{l}\text { Analyze } \\
\text { neuromuscular, } \\
\text { physiological, } \\
\text { and perceptual } \\
\text { marker chang- } \\
\text { es for routine } \\
\text { evaluation of } \\
\text { fatigue and } \\
\text { recovery in } \\
\text { high endur- } \\
\text { ance strength } \\
\text { training. }\end{array}$ & $\begin{array}{l}\text { Strength } \\
\text { training } \\
\text { with } \\
\text { traditional } \\
\text { method- } \\
\text { ology, } \\
\text { pyramid, } \\
\text { super- } \\
\text { sets of } \\
\text { agonists } \\
\text { agd super } \\
\text { series of } \\
\text { agonist } \\
\text { pairs }\end{array}$ & $\begin{array}{l}\text { Individualized mus- } \\
\text { cle endurance con- } \\
\text { sisted of } 2 \text { sets of } 20 \\
\text { repetitions }(2 \times 20) \text { a a } \\
53 \% \text { of } 1 R M \text { with a } \\
45-\text { second rest period } \\
\text { between sets. The } \\
\text { hypertrophy train- } \\
\text { ing consisted of } 3 \times \\
10 \text { at } 70 \% \text { of } 1 \text { RM } \\
\text { with a } 120 \text {-second } \\
\text { rest period between } \\
\text { series. For strength, } \\
\text { the workouts were } 5 \\
\times 5 \text { at } 85 \% \text { of } 1 \text { RM } \\
\text { with a } 180-\text { second } \\
\text { rest period between } \\
\text { sets. }\end{array}$ & $\begin{array}{l}\text { Paired agonist } \\
\text { super series } \\
\text { caused } \uparrow(\mathrm{p}< \\
0.05) \text { in }[\mathrm{La}] \\
\text { and RPE. }\end{array}$ & $\begin{array}{c}\text { CMJ and iso- } \\
\text { metric MVC } \\
\downarrow \downarrow \mathrm{p}<0.001 \\
\text { and } \mathrm{p}<0.008, \\
\text { respectively) }\end{array}$ & $\downarrow$ \\
\hline
\end{tabular}




\begin{tabular}{|c|c|c|c|c|c|c|c|}
\hline Bartolomei et al. ${ }^{50}$ & 2017 & $\begin{array}{l}\text { To compare } \\
\text { the acute } \\
\text { effects of four } \\
\text { different resis- } \\
\text { tance training } \\
\text { methodolo- } \\
\text { gies aimed at } \\
\text { hypertrophy. }\end{array}$ & $\begin{array}{l}\text { High } \\
\text { intensity } \\
\text { over- } \\
\text { loaded } \\
\text { squat and/ } \\
\text { or high } \\
\text { volume } \\
\text { overload- } \\
\text { ed squat }\end{array}$ & $\begin{array}{l}\text { Squat with overload } \\
4 \text { series force of } \\
5 \mathrm{RM} \text { (potentiation } \\
\text { condition) }\end{array}$ & $\begin{array}{c}\text { LDH, CK and } \\
\mathrm{Mb} \uparrow(\mathrm{p}<0.05) \\
\text { in HV and HI. } \\
\text { Cortisol and } \\
\text { IL-6 } \uparrow(\mathrm{p}< \\
0.001 \text { and } \mathrm{p}< \\
0.05 \text { respective- } \\
\text { ly) in HV. }\end{array}$ & $\begin{array}{c}\text { Maximum } \\
\text { torque } \downarrow \text { ( }<< \\
0.05) \text { in occlu- } \\
\text { sion training }\end{array}$ & $\mathrm{HV} \downarrow$ \\
\hline de Almeida et al. ${ }^{23}$ & 2017 & $\begin{array}{l}\text { To compare the } \\
\text { variables releted } \\
\text { to asymmetry, } \\
\text { peak torque, and } \\
\text { fatigue index in } \\
\text { the traditional } \\
\text { strength training } \\
\text { method and the } \\
\text { occlusion train- } \\
\text { ing method. }\end{array}$ & $\begin{array}{c}\text { Tradi- } \\
\text { tional } \\
\text { strength } \\
\text { train- } \\
\text { ing and } \\
\text { occlusion } \\
\text { training }\end{array}$ & $\begin{array}{c}\text { Resistance stroke } \\
\text { followed immedi- } \\
\text { ately by a force load } \\
\text { or force session fol-- } \\
\text { lowed by resistance } \\
\text { stroke. }\end{array}$ & $\begin{array}{l}\text { Training with } \\
\text { occlusion } \uparrow(\mathrm{p} \\
<0.05) \text { lactate } \\
\text { dehydrogenase } \\
\text { levels, [La], } \\
\text { fatigue index } \\
\text { and CK }\end{array}$ & $\begin{array}{l}\text { CMJ, times } 50 \\
\text { meters, was ns }\end{array}$ & $\downarrow$ \\
\hline Johnston et al. ${ }^{51}$ & 2017 & $\begin{array}{l}\text { To examine the } \\
\text { acute effect of } \\
\text { the sequence } \\
\text { of strength and } \\
\text { speed training on } \\
\text { neuromuscular, } \\
\text { endocine, and } \\
\text { physiological } \\
\text { responses for } 24 \\
\text { hours. }\end{array}$ & $\begin{array}{l}\text { Strength } \\
\text { training } \\
\text { followed } \\
\text { by speed } \\
\text { training } \\
\text { and vice } \\
\text { versa }\end{array}$ & $\begin{array}{c}5 \text { sets of exercise } \\
\text { (i.e., two sets at } \\
85 \% \text { of } 1 \text { RM with } \\
\text { three repetitions per } \\
\text { series and three sets } \\
\text { at } 90 \% \text { of } 1 \text { RM with } \\
\text { two repetitions per } \\
\text { series). }\end{array}$ & $\begin{array}{c}{[\mathrm{La}] \uparrow(\mathrm{p}<} \\
0.05 \text { ) } \\
\text { diate- } \\
\text { diaty after } \\
\text { speed training. } \\
\text { CK, cortisol, } \\
\text { testosterone, and } \\
\text { DOMS were ns } \\
\text { in both proto- } \\
\text { cols. }\end{array}$ & $\begin{array}{l}\text { SJ and CMJ } \downarrow \\
(\mathrm{p}<0.05) \text { in } \\
\text { HI group }\end{array}$ & $=$ \\
\hline Andreatta et al. ${ }^{52}$ & 2018 & $\begin{array}{l}\text { Assess whether } \\
\text { celf-free eNAA } \\
\text { (ctDNA) } \\
\text { levels increased } \\
\text { immediately after } \\
\text { light and heavy } \\
\text { endurancee exer- } \\
\text { cise and whether } \\
\text { ctDNA levels } \\
\text { are associated } \\
\text { with functional } \\
\text { muscle capacity } \\
\text { up to } 4 \text { hours } \\
\text { after an exercise } \\
\text { session. }\end{array}$ & $\begin{array}{l}\text { Leg press } \\
\text { HI and LI }\end{array}$ & $\begin{array}{l}3 \text { series of hip flex- } \\
\text { ion, hip extension, } \\
\text { and hip abduction ex- } \\
\text { ercises by an elastic } \\
\text { band. }\end{array}$ & $\begin{array}{c}{[\mathrm{La}] \uparrow(\mathrm{p}<0.05)} \\
\text { in both groups. } \\
\mathrm{CK} \text { and cffNA } \\
\text { concentration } \uparrow \\
\mathrm{p}<0.05) \text { in the } \\
\text { HI group }\end{array}$ & $\begin{array}{l}\text { ROM } \downarrow \text { (p } \\
<0.05 \text { ) in } \\
\text { both groups; } \\
\text { however, HI } \\
\text { eccentric exer- } \\
\text { cise combined } \\
\text { with occlusion } \\
\text { was recov- } \\
\text { ered at } 24 \\
\text { hours, while } \\
\text { no occlusion } \\
\text { recovered at } \\
48 \text { hours. }\end{array}$ & $\underset{\text { protocols }}{\downarrow \text { in HI force }}$ \\
\hline Curty et al. ${ }^{53}$ & 2018 & $\begin{array}{l}\text { To assess acute } \\
\text { effectco of ecere- } \\
\text { tric HI exercise } \\
\text { combined with } \\
\text { occlusion on } \\
\text { markers on mus- } \\
\text { cle damage and } \\
\text { perceptual and } \\
\text { cardiovascular } \\
\text { responses. }\end{array}$ & $\begin{array}{c}\text { Eccentric } \\
\text { exercise } \\
\text { in elbow } \\
\text { flexion } \\
\text { with } \\
\text { occlu- } \\
\text { sion and } \\
\text { without } \\
\text { occlusion }\end{array}$ & $\begin{array}{l}3 \text { sets of } 8 \text { repetitions } \\
\text { until failure, while } \\
\text { the second protocol } \\
\text { was separated by } 14 \\
\text { days and consisted of } \\
3 \text { sets by } 4 \text { repeti- } \\
\text { tions both protocols } \\
\text { at } 80 \% \text { of } 1 \text { RM }\end{array}$ & $\begin{array}{l}\text { DOMS } \uparrow(\mathrm{p}< \\
0.05) \text { in eccen- } \\
\text { tric Hi exercise } \\
\text { combined with } \\
\text { occlusion. HR } \\
\uparrow(\mathrm{p}<0.05) \text { in } \\
\text { both groups }\end{array}$ & $\begin{array}{l}\text { Maximum } \\
\text { absolute and } \\
\text { relative mus- } \\
\text { cle power } \downarrow \text { (P } \\
<0.0001)\end{array}$ & $\begin{array}{c}\downarrow \text { in both } \\
\text { protocols, but } \\
\text { non-occlu- } \\
\text { sive training } \\
\text { presents more } \\
\text { durable } \downarrow\end{array}$ \\
\hline dos Santos et al..$^{54}$ & 2018 & $\begin{array}{l}\text { To investigate } \\
\text { cardiovascular, } \\
\text { neuromuscular, } \\
\text { and metabolic } \\
\text { responses of } \\
\text { physically active } \\
\text { subjects during } \\
\text { a session of sled } \\
\text { drag with resis- } \\
\text { tance (RST). }\end{array}$ & $\begin{array}{l}\text { Sled drag } \\
\text { with re-- } \\
\text { sistance }\end{array}$ & $\begin{array}{l}\text { Strength ( } 4 \times 6 \text { repeti- } \\
\text { tions, } 85 \% \text { of } 1 \text { RM, } 900 \\
\text { sof total rest), hypettro- } \\
\text { phy } 5 \times 10 \text { repetitions, } \\
70 \% \text { of } 1 \text { RM, } 360 \mathrm{~s} \\
\text { total rest), group } 1: 4 \times 6 \\
\text { simple repetitions, } 85 \% \\
\text { of } 11 \mathrm{RM}, 1400 \mathrm{~s} \text { of total } \\
\text { rest and group } 2: 4 \times 6 \\
\text { simple repetitions, } 90 \% \\
\text { of } 1 \mathrm{RM}, 1400 \text { s total rest }\end{array}$ & $\begin{array}{c}\mathrm{HR} \uparrow(\mathrm{P}<0.05) \\
\text { and }[\mathrm{La}] \uparrow(\mathrm{P}< \\
0.0001)\end{array}$ & $\begin{array}{c}\text { Distance } \\
\text { in grenade } \\
\text { launch } \uparrow(\mathrm{p}< \\
0.05)\end{array}$ & $\downarrow$ \\
\hline
\end{tabular}

\begin{tabular}{|c|c|c|c|c|c|c|c|}
\hline Ojeda et al. ${ }^{29}$ & 2018 & 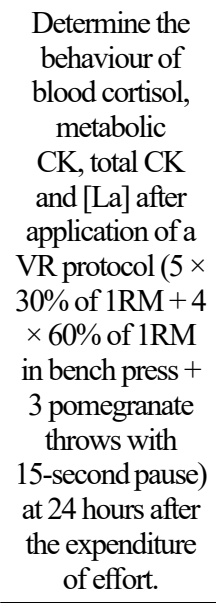 & $\begin{array}{l}\text { Variable } \\
\text { resistance } \\
\text { protocol }\end{array}$ & $\begin{array}{l}\text { Four sets of } 5 \text { rep- } \\
\text { etitions a } 30 \% \text { of } \\
1 \text { RM }+4 \text { repetitions } \\
\text { at } 60 \% \text { of } 1 \mathrm{RM}+3 \\
\text { pomegranate throws } \\
\text { separated by } 15 \\
\text { seconds. }\end{array}$ & $\begin{array}{l}\text { [La], cortisol } \\
\text { and metabolic } \\
\text { CK were ns }\end{array}$ & $\begin{array}{l}\text { Total load } \\
\text { volume } \downarrow \text { ( } \mathrm{p} \\
<0.05) \text { in } \\
\text { 24-hour rest } \\
\text { protocol }\end{array}$ & $\uparrow$ \\
\hline Miranda et al. ${ }^{55}$ & 2018 & $\begin{array}{l}\text { Examine the } \\
\text { effect of differ- } \\
\text { ent recovery } \\
\text { periods ( } 24, \\
48 \text {, and } 72 \\
\text { hours) between } \\
\text { repeated resis- } \\
\text { tance training } \\
\text { (RT) sessions } \\
\text { for upper body } \\
\text { muscles on } \\
\text { repetitive per- } \\
\text { formance and } \\
\text { blood lactate } \\
\text { responses in } \\
\text { trained men. }\end{array}$ & $\begin{array}{c}\text { Press } \\
\text { banking } \\
\text { with } 24, \\
48 \text { or } 72 \\
\text { hours rest }\end{array}$ & $\begin{array}{l}\text { Three sets of unilat- } \\
\text { eral knee extension } \\
\text { exercises in LI-BFR } \\
\text { and LI } 15 \text { repeti- } \\
\text { tions; } 20 \% \text { of } 12 M \text { ) } \\
\text { and } \mathrm{HI}(8 \text { repetitions; } \\
80 \% \text { of } 11 \mathrm{MM}) \text {. }\end{array}$ & $\begin{array}{c}{[\mathrm{La}] \uparrow(\mathrm{p}<0.05)} \\
\text { in } 24 \text {-hour rest } \\
\text { protocol }\end{array}$ & $\begin{array}{l}\text { Number of } \\
\text { repetitions } \\
\text { performed } \downarrow \\
(\mathrm{p}<0.05) \text { in } \\
\text { series } 2 \text { and } 3 \text {. } \\
\text { Average pro- } \\
\text { pulsion speed } \\
\text { of repetitions } \\
\text { and CMJ } \downarrow(\mathrm{p} \\
<0.05) \text { after } \\
24 \text { and } 48 \text { hrs. }\end{array}$ & $\begin{array}{l}\downarrow \text { in 24-hour } \\
\text { rest protocol }\end{array}$ \\
\hline Párraga-Montilla et al. ${ }^{56}$ & 2018 & $\begin{array}{l}\text { Explore the } \\
\text { acute and } \\
\text { delayed effects } \\
(24 \text { and } 48 \\
\text { hours after } \\
\text { exercise) of } \\
\text { a resistance } \\
\text { training ses- } \\
\text { sion leading to } \\
\text { muscle failure. }\end{array}$ & $\begin{array}{l}\text { Squat } \\
\text { with over- } \\
\text { load until } \\
\text { muscle } \\
\text { failure }\end{array}$ & $\begin{array}{l}\text { Twice daily training, } \\
\text { morning }(9 \mathrm{AM}) \text { and } \\
\text { afternoon }(3 \mathrm{PM}) \text {, on } \\
6 \text { consecutive days, } \\
\text { resulting in a total of } \\
11 \text { training sessions } \\
\text { (training programa } \\
\text { consisted of multiple } \\
\text { resistance and basic } \\
\text { multijump combined } \\
\text { with maximum } \\
\text { eccentric strength } \\
\text { exercises, focusing } \\
\text { primarily on parallel } \\
\text { squat training). }\end{array}$ & $\begin{array}{c}\mathrm{RPE} \text { and [La] } \uparrow \\
\quad(\mathrm{p}<0.05) .\end{array}$ & $\begin{array}{l}\text { Both proto- } \\
\text { cols produced } \\
\uparrow(\mathrm{p}<0.05) \\
\text { muscle size } \\
\text { and muscle } \\
\text { function. }\end{array}$ & $\downarrow$ \\
\hline Sieljacks et al. ${ }^{57}$ & 2018 & $\begin{array}{l}\text { To compare } \\
\text { training with } \\
\text { occlusion } \\
\text { performed to } \\
\text { failure versus } \\
\text { occlusion } \\
\text { without failure } \\
\text { with regard } \\
\text { to changes in } \\
\text { muscle size, } \\
\text { function, and } \\
\text { perceptual } \\
\text { responses. }\end{array}$ & $\begin{array}{l}\text { Training } \\
\text { with oc- } \\
\text { clusion }\end{array}$ & 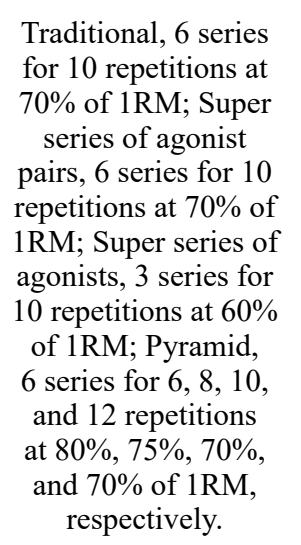 & $\begin{array}{c}\text { RPE and DOMS } \\
\downarrow(p<0.05) \\
\text { in occlusion } \\
\text { without failure } \\
\text { as compared to } \\
\text { occlusion until } \\
\text { failure. }\end{array}$ & Not measured & $\begin{array}{c}\downarrow \text { in occlusion } \\
\text { up to judg- } \\
\text { ment by over } \\
\text { a protocol } \\
\text { of occlusion } \\
\text { without judg- } \\
\text { ment }\end{array}$ \\
\hline
\end{tabular}




\begin{tabular}{|c|c|c|c|c|c|c|c|}
\hline Wertheimer et al. ${ }^{19}$ & 2018 & 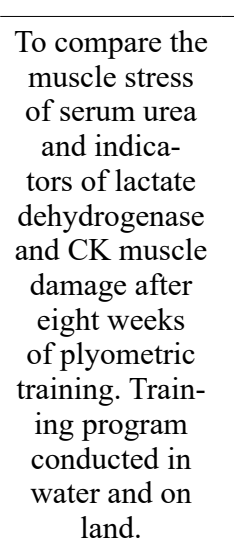 & $\begin{array}{l}\text { Plyyo- } \\
\text { trotric } \\
\text { traning } \\
\text { in water } \\
\text { and or on } \\
\text { soil }\end{array}$ & 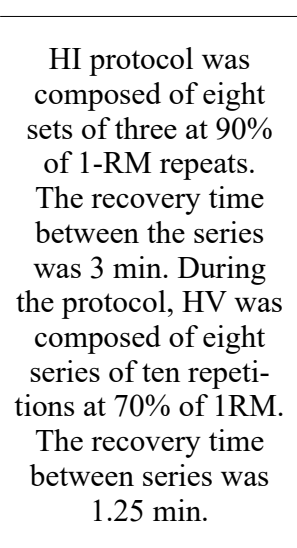 & 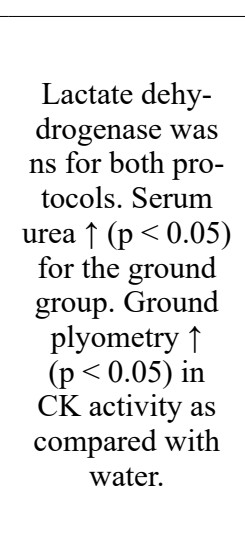 & 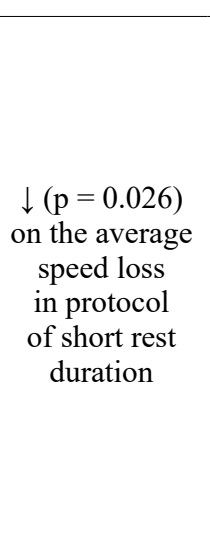 & $\begin{array}{l}\text { It is stated } \\
\text { that he plyo- } \\
\text { metric group } \\
\text { in water } \\
\text { presents few- } \\
\text { er indicators } \\
\text { of muscle } \\
\text { damage. }\end{array}$ \\
\hline Tufano et al..${ }^{8} 8$ & 2019 & $\begin{array}{l}\text { Compare } \\
\text { kinematic, } \\
\text { metabolic, } \\
\text { endocrine, } \\
\text { and perceptual } \\
\text { responses of } \\
\text { three backward } \\
\text { squat protocols } \\
\text { with equal } \\
\text { loads, number } \\
\text { of repetitions, } \\
\text { and the total } \\
\text { duration of } \\
\text { rest. }\end{array}$ & $\begin{array}{l}\text { Squat } \\
\text { with an } \\
\text { oover } \\
\text { load of } \\
\text { dififerent } \\
\text { resting } \\
\text { protocols }\end{array}$ & 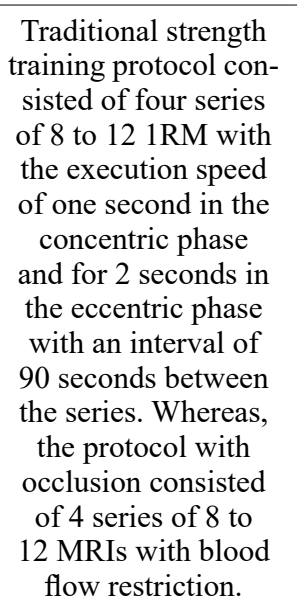 & $\begin{array}{l}\text { All rest proto- } \\
\text { cols led to } \uparrow(\mathrm{p} \\
<0.05) \text { RPE and } \\
\text { [La], which re- } \\
\text { mained elevated } \\
\text { up to } 30 \text { minutes } \\
\text { after exercise. }\end{array}$ & $\begin{array}{l}\text { 1RM and } \\
\text { CMJ were ns }\end{array}$ & $\begin{array}{l}\text { I when the } \\
\text { protocol had } \\
\text { a short rest } \\
\text { period }\end{array}$ \\
\hline
\end{tabular}

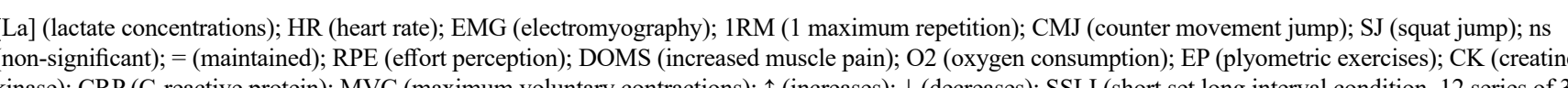

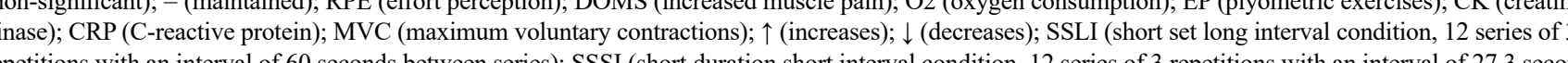

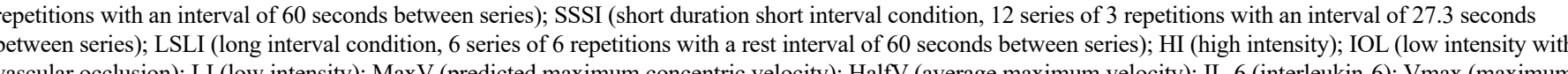

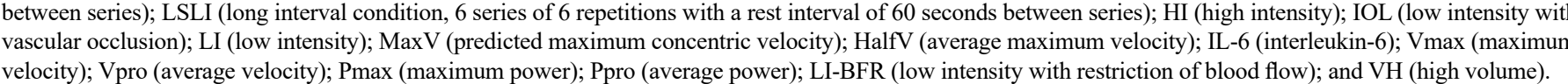

\section{Discussion}

At the end of the systematic review and based on the main objective that sought to find evidence of alterations in muscle fatigue indicators during and after strength training, 39 studies were found between January 2009 and January 2019. Of which only In 4 there was evidence of increased performance despite having indicators of altered muscle fatigue. This may be due to the normal physiological response of the subjects. This evidence
allowed us to visualize that there were protocols for the development of strength that generate alterations in muscle fatigue markers, such as [La], HR, RPE, DOMS, the variation of MR and ammonium. This shows that there are force protocols that, only be performed in some types of populations. Therefore, and for a better understanding, the different protocols for the development of strength and the changes they generate in muscle fatigue markers will be stratified separately.

. Plyometric training and muscle fatigue

Drinkwater et al..$^{14}$, following an acute plyometric exercise intervention in recreational rugby players, observed significant
decreases in maximum voluntary contractions $(\mathrm{MVC})(\mathrm{p}<0.05)$ and torque development rate $(\mathrm{p}<0.01)$, triggering peripheral fatigue and resulting in decreased performance. Skurvydas et al. ${ }^{18}$, using plyometrics in physically active male students, recorded that the strength of MVC decreased significantly after two continuous series of high-intensity jumps $(\mathrm{p}<0.05)$, while the DOMS increased significantly $(\mathrm{p}<0.05)$. Similarly, Brown et al.16 also showed increases in HR and [La] after an acute plyometric session in recreationally trained men and women ( $\mathrm{p}$ occasions as precursor variables of fatiguet

Kamandulis et al ${ }^{30}$ after nine sessions of plyometric intervention in physically active athletes, reported that increases injumping training load lead to an increase in muscle fatigue markers, thus suppressing acute mechanical function after exercise; however, after three weeks of training and adequate recovery, an increase in overall muscle performance was observed. In this sense, it has been observed that between plyometric exercise sessions, and for adequate recovery, there must be a 72-hour rest period. In this fatigue indicators ${ }^{17,41}$ can be reduced, way, alterations in muscle
Chatzinikolaou et al. ${ }^{17}$ showed that an acute session of plyometrics in healthy men, with a pause of 2 minutes between series (5 series of 10 repetitions) and 5 minutes of rest between jumping of obstacles and jumps with a fall from a plyometric box, can induce a substantial decrease in jump performance resulting from increases in [ $\mathrm{La}](\mathrm{p}<0.001)$, as well as substantial alterations in blood cind related to muscle damage up to 72 hours after the intervention. These findings are similar to those found by Thomas et al ${ }^{141}$, who state that plyometric exercises require 72 hours to decrease exercise-induced levels of muscle fatigue.

2. Bodypump® Training and Muscle Fatigue

The Bodypump® is a methodology that consists of training with bars, occupying loads ranging from $45-60$ minutes with a standardized sequence of music ${ }^{26}$. This program has shown to be effective in improving maximum strength and muscular endurance of the lower extremities in untrained women 2 . In this sense, in research carried HR after 12 weeks of trinin in sedentary women $(p>0.05)$. On the other hand, Oliveira et al 26 after an acute Bodypump $\mathbb{R}$ intervention, showed significant increases in [La] and $\mathrm{HR}(\mathfrak{p}<0.05)$; variables considered as precursors of muscle fatigue ${ }^{17}$. However, Oliveira et al..$^{26}$ stated that there was no significant correlation between the electromyographic activity of the muscle and the [La] and HR. Although Bodypump® training produces acute fatigue ${ }^{26}$, this would be sthicient to increase hismaximum strengh endurance of the lower extremities in untrained subjects ${ }^{26,27}$.

3. Training with occlusion and muscle fatigue

In recent times, low load training with occlusion has attracted the attention of trainers as both a possible alternative to high endurance increase muscle strength and hypertrophy ${ }^{21}$ In this sense, Okuno et ${ }^{2}{ }^{21}$ indicated that training with occlusion appears to be more favorable than traditional force training without occlusion ${ }^{12,25}$. Similarly, had preventive effects on indicators of muscle fatigue and indirect responses induced by eccentric exercise. Therefore, training with occlusion would produce less metabolic stress ${ }^{21,42}$. Even training with occlusion would be recommended as a training method in those subjects who present with cardiovascular problems and who cannot perform strength exercises over $80 \%$ of $1 \mathrm{RM}^{21}$. Sieljacks et al. failure in repetitions in untrained subjects allows for increases in discomfort, and less appearance of DOMS. Howerer ulike the findings reported by Okuno et al 21 $^{21}$ Curty et $21^{42}$, and Sieljacks et al $1^{43}$, Poton, Polito ${ }^{22}$ established that healthy, trained subjects who undergo occlusion training may have muscle fatigue due to the increase in [La], as well as an increase in $\operatorname{RPE}(\mathrm{p}<0.05)$.

In addition to what was previously reported by Poton, Polito ${ }^{22}$, there is a study conducted by Almeida et al. ${ }^{23}$. These researchers obtained a higher level of fatigue after the application of a force with the occlusion method; this fatigue was associated with increases in [La] and with increases in BSDM indicators, such as $\mathrm{CK}$ and Motriz, Rio Claro, v.26, Issue 3, 2020, e1020006 lactate dehydrogenase $(p<0.05)$, as well as higher values in the fatigue index when compared to a traditional force method in subjects with experience in strength training. Therefore, these BSDM would have a direct relationship with the increase in muscle fatigu indicators However, more studies are needed that can clarify ists performine. this review used a 1-minute pause between series.

4. Variable resistance and muscle fatigue training

Variable resistance $(\mathrm{RV})$ corresponds to the change of intensity during the application of force training load, within the various variable resistance, and intra-series variable resistance ${ }^{4}$. Somettypes of VR have reported increases in the indicators of muscle fatigue and increases in the DOMS and $[\mathrm{La}]^{24}$. On the other hand, VR protocols cause general and local fatigue in military athletes that is related to the increase in $[\mathrm{La}](\mathrm{p}<0.001)$ and decreases in average power $(\mathrm{p}$ et $21^{1}$, these same authors in other research did not repot tinceses in muscle fatigue indicators after a VR protocol. This would allow inferring that the athletes were in an anabolic process and without the presence of muscle fatigue, reflecting an increase in explosive strength using a grenade throw ${ }^{29}$

5. Conventional strength and muscle fatigue training This type of training has been used over the years occupying high volume load protocols (muscular endurance) $)^{45,46}$, high-intensity exercises (maximum strength) ${ }^{4,4}$, or muscular hypertrophy programmes ${ }^{2,13}$. In this sense, it has been reported that high volume muscle endurance training performed at a low-intensity of 1RM regardless of whether it is performed with shortintervals $(1$ minute) long intervals ( 3 minutes) of rest between series ${ }^{36}$ Similarly Hardec et al ${ }^{35}$, showed that high-volume power clean exercises, performed at low intensity on trained subjects, increase the RPE independent of rest time between series $(\mathfrak{p}<0.05)$, which is directly related to decrease in output power $(p<0.05)$. Likewise, Date et al..$^{15}$ showed a significant increase in $[\mathrm{La}]$ in physically active males $(p<0.05)$ after power clean training that considered a high load volume. Similarly, Rogatzki et a $1 .{ }^{45}$ showed that a protocol of muscular resistance, when compared with a protocol of hypertrophy and maximum strength, significantly increased the blood levels of ammonium and lactate in adolescents $(\mathrm{p}<0.05)$. These findings are consistent with other research hat reported muscle fatigue following the use of high volet $1 l^{47}$, it was concluded that acute interventions with high-intensity strength exercises (5RM) produce neither alterations in [La] nor increases in RPE. Therefore, an acute session of 4 series of 5RM could enhance performance in cyclists ${ }^{4}$.

On the other hand, Nicholson et al. ${ }^{13}$ showed increases in [La] in maximum strength and hypertrophy programs in trained subjects $(\mathrm{p}<0.001)$, while Walker et al. ${ }^{12}$ and Izquierdo et al. showed increases in $[\mathrm{La}]$ during hypertrophy sessions $(\mathrm{p}<$ 0.05 ) and increases in ammonia and uric acid concentrations maximum strength sessions, respectively; both studies were in 
physically active subjects $(p<0.05)$. However, Bartolomei et al.$^{49}$, after comparing two strength protocols (high load volume versus high intensity) in subjects with strength experience, concluded that high volume training induces greater muscle fatigue due to the increase in [La]. Thus, endurance training up to muscle failure significantly reduces metabolic recovLikewise, Andreatta t al $^{48}$ showed is hours after exercise application of a high-intensity force protocel ( $80 \%$ of 1 RM) in healthy subjects with strength experience. On the other hand, Silva et al ${ }^{47}$ showed no increase in [La] after a high-intensity protocol. Bartolomei et al. ${ }^{49}$ also showed that the high-volume protocol generates greater muscle fatigue than a high-intensity protocol. This may be associated with the number of repetitions since Bartolomei et al. ${ }^{40}$ evaluated only 3 repetitions versus 10 repetitions performed in the Andreatta et al ${ }^{48}$ protocol. The latter protocol could be considered a high-volume protocol ${ }^{15}$. Therefore, strength training up to muscle failure produces significant increases in metabolic stress, with greater muscle fatigue in the subjects who practice $i t$. This is why the large metabolic stress suggest a lower use of force protocols with high volume $\mathrm{e}^{46,51}$.

In conventional strength protocols, BSDMs also have a close relationship to increased indicators of muscle fatigue. In this sense, Bartolomei et al..$^{49}$, along with evidence of an increase in muscle fatigue indicators ([La]), also observed alterations in $\mathrm{CK}$, cortisol, and IL-6 $(\mathrm{p}<0.001)$ in high-volume training, which is possibly associated with post-exercise muscle damage. Oher research also reported alterations in both fatigue indicators $5^{2,34}$ and BSDM after high volume training ${ }^{34}$. Therefore, a direct association between indicators of muscle would discourage high-volume strength protocols.

. Eccentric strength and muscle fatigue training Both high-intensity and low-intensity eccentric exercises have been shown to produce muscle fatigue, resulting in dethis sense, Fernandez-Gonzalo et al ${ }^{25}$, after a first eccentric training session, showed significant increases in the [La] in the group of healthy and physically active males, however these same variables after 15 sessions did not present alterations, so a muscular adaptation to the eccentric training was inferred. Gauche et al." reported that he maximum voluntary contraction was significantly reduced after eccentric exercise and by $25 \%$ after low-inten subjects. These voluntary maximum contraction values remained reduced after 48 hours for both high-intensity and low-intensity exercise $(\mathfrak{p}<0.001)$. These results are similar to conventional strength training in which low-intensity strength sessions have found to induce an increase in muscle fatigue ${ }^{4 /}$ and a decrease in performance $e^{48}$. Finally, alterations in the BSDM continue to be directly related to markers of muscle fatigue; thus, Fernandez-Gonzalo et al. ${ }^{25}$, along with evidence of increases in the [La], also present alchions in blood CK.
7. Different times of rest in the training of strength and muscular fatigue

Thas been established that strength training for 6 consecutive days induces significant alterations in DOMS, stress, and perceived recovery, which is directly related to a decrease in $1 \mathrm{RM}$, thus inducing muscle fatigue in both men and women ${ }^{35}$. Also,
DOMS levels have been reported to increase significantly $(\mathrm{p}<$ 0.05 ) with either short 1-minute rest intervals or long 3-minute rest intervals between series ${ }^{36}$. Paulo et al ${ }^{54}$ indicated that a 1 -minute break between series results in greater production of average power in exercise sessions aimed at developing muscle power in healthy young people. However, Miranda et al..$^{55}$ in the context of neural activation, stated that a 3 -minute rest interval between series may represent a neuromuscular window between a state of fatigue and a state of the total recovery in trained women. These same researchers examined the effect of the different recovery periods (24, 48, and 72 hours) between sessions of strength training using press banking in trained subjects. At the end, they concluded that a recovery period of only 24 hours
induces an increase in $\left[\mathrm{La}\right.$ and RPE $(\mathrm{p}<0.05)^{56}$, variables that are considered as indicators of muscular fatigu ${ }^{35}$ and that are directly related to the decrease in performance ${ }^{48}$. When comparing the kinematic, metabolic, endocrine, and perceptual responses of three overloaded squatting protocols in trained subjects. Tufano et al. ${ }^{57}$ concluded that muscle fatigue occurs by increasing [La] and RPE, regardless of the organization of rest time used. Thus, Ammar et al..$^{.8}$ showed increases in $[\mathrm{La}]$ and $\operatorname{RPE}(\mathrm{p}<0.01)$ in weightliffers. These findings were independent of training schedules during the day (morning, afternoon, or night), and BSDM continued to be elevated after 48 hours of recovery $(p<0.05)$. Thus, $[\mathrm{La}]$ and $R P$ h have also been altered in orher studies ${ }^{12,1,3,3}$ and declared as precursors of muscle fatigue

In general terms, and based on the systematic review, it is suggested hat strenged sessions be separated by 72 hours to et al $1^{58}$ and Tufano et al $1^{57}$ also showed an increase in BSDM et al. ${ }^{50}$ and Tufano et al. ${ }^{57}$ also showed an increase in BSDM
simultaneously with increases in muscle fatigue indicators, so this history continues to demonstrate a close relationship between muscle fatigue indicators and BSDM.

8. Concurrent training and muscle fatigue

In this type of training, Taipale et al ${ }^{59}$ showed significant increases $(p<0.05)$ in $[\mathrm{La}]$ after a resistance run intervention followed by a strength protocol or vice versa in both trained men and women, but also showed increases in CK role in the decrese of ast variable can play a determining recovery $y^{121736.59}$. On the other hand, not call racities during shown an increase in variables that induce fatigue and muscle damage after a concurrent protocol. Johnston et al ${ }^{60}$ only reported an increase in $[\mathrm{La}]$ and not BSDM after each speed protocol followed by strength training, but not when strength was trained and then speed. Due to the lack of evidence, more studies are needed to address the variables involved, and thus clarify the order of exercises at the time of concurrent training and mitigate possible decreases in performance in athletes.
Conclusions

At the end of the systematic review, it was shown that the different training methodologies for strength development generate increases in muscle fatigue indicators, and the increase generated in the differnt muscle fargue indicaros depends both on the methodology used and on the type of population, sex, level of training and type of sport.

are different ways of quantifying fatigue in strength training. Among the most
commonly used fatigue indicators are [La], HR, RPE, DOMS, $M R$ variation, and ammonium. The most-reported indicators are [La], HR, and RPE. Finally, considering that more studies are still needed to determine the real effect of these training methods on fatigue indicators, and in light of the facts, there are indications that plyometric training, training with variable resistance and ones that could incur the greatest increase in muscle fatigue.

Limitations

One limitation of the study is to a lack of homogeneity associated across the studies, they do not allow to perform a meta-analysis.

Practical Applications

Based on the results of the systematic review, and to minimize muscle fatigue levels, increasing load volumes, and enhancing athlete permance, some considerations for stratified methods are presented. 1. Plyometric training: As it has a great impact, it should be applied to athletes capable of lifting twice their body weight should be greater than 2 minutes and there should be a minimum of 72 hours between sessions. Although an indicator of fatigue for this method is the impossibility of reaching the training heights established for athletes, [La] was used as an indicator of fatigue in most of the research consulted.

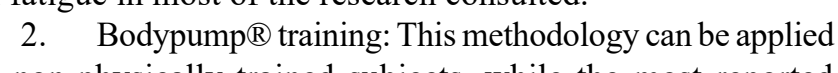
to non-physically trained subjects, while the most reported fatigue indicators are $\mathrm{HR}$ and $[\mathrm{La}]$

be used in both trained and untrained subjects. In most of the investigations consulted, they used a 1-min most of between series. This pause triggered increases in muscle fatigue indicators in some studies. As a result, new research is suggested to clarify the optimal pause time between series, while the suggested fatigue indicators are perceived DOMS, $\mathrm{RPE}$, and [La].

4. Variable endurance training: This type of protocol should be aimed at athletes, being discouraged in physically inactive subjects. Although it is important, in order to establish the pause, to consider the variation of the intensity within the series, pauses of 15 seconds are suggested. The fatigue indicators with the greatest evidence are perceived DOMS and [La]. 5. Conventional strength training: This type of protocol can be used in inactive subjects as well as athletes. However, and with the purpose of mitigating muscular fatigue alterhigh-intensity sessions. It is recommended that the pause time between series be greater than 3 minutes and the rest between each session should be around 72 hours, while the suggested fatigue indicators are RPE, DOMS perceived, and [La]. 6. Eccentric training: This type of protocol should be used in physically active subjects. Evidence showed that high-intensity executions have less alteration in muscle fatigue indicators but more studies are needed to determine the effect of these protocols on fatigue indicators. However, the suggested rest perione between each session should be are the the suggested fatigue indicators are [La].

7. Different rest times in strength training: This section suggests starting with strength protocols that include a minindividualized guidelines for each strength protocol. However, the 72 hours of rest between each session are independent of the type of strength training while the fatigue indicators are [La] and RPE.

8. Concurrent training: this type of protocol should be occupied by trained subjects. After the review, it is suggested to first train strength exercises and then speed exercises, but more evidence is needed to clarify the order of execution of concurrent training. Finally, the fatigue indicators used for these protocols are [La].

\section{References}

Ojeda ÁCH, Ríos LJC, Barrilao RG, Ríos IJC, Serrano PAC. cute effect of Complex Training protocol on grenade throwing velocity on military pentathletes. Arch Med del Deport. 2016;33(6):367-374

2. Pareja-Blanco F, Rodriguez-Rosell D, Sanchez-Medina L, Gorostiaga EM, Gonzalez-Badillo JJ. Effect of Movement Velocity during Resistance Training on Neuromuscular Performance. Int J Sports Med. 2014;35(11):916-924. Folland IP. Newassey GJ, Maden-Wilkinson TM, Lanza MB, Te resistance training vs untrained. Scand J Med Sci Sports. 2019;29(3):348-359.

DA, JU, Jakovljevic DG, Kozic DB, Dragnic NR, Brodie extensor muscles to twelve-week self-perceived maximal resistance training Clin Physiol Funct Imaging. 2010;30(6):413419. doi:10.1111/j.1475-097X.2010.00957.x.

Sabido R, Penaranda M, Hernandez-Davo JL. Comparison of acute responses to four different hypertrophy-orient-
ed resistance training methodologies. Eur J Hum Mov. 2016;37:109-121. 6. Ceroni D, Martin XE, Delhumeau C, Farpour-Lambert NJ.
Bilateral and gender differences during single-legged vertical 
jump performance in healthy teenagers. J Strength Cond Res. 2012;26(2):452-457.

Grgic J, Lazinica B, Garofolini A, Schoenfeld BJ, Saner NJ Mikulic $P$. The effects of time of day-specific resistance training on adaptations in skeletal muscle hypertrophy and muscle strength: A systematic revaw.

8. Schoenfeld BJ, Grgic J, Krieger J. How many times per week should a muscle be trained to maximize muscle hypertrophy? should a muscle be trained to maximize muscle hypertrophy? A systematic review and meta-analysis of studies examining 2019;37(11):1286-1295.

9. Grgic J, Schoenfeld BJ, Latella C. Resistance training frequency and skeletal muscle hypertrophy: A review of available evidence. J Sci Med Sport. 2018;22(3):361-370,

10. Grgic J, Schoenfeld BJ, Davies TB, Lazinica B, Krieger JW, Pedisic Z. Effect of resistance training frequency on gains in muscular strength: a systematic review and meta-analysis. Sports Med. 2018;48(5):1207-1220.

1. Couto BP, Silva HR, Filho AG, Silveira Neves SR, Ramos MG, Szmuchrowski LA, et al. Acute Effects of Resistance Training

Walker S, Davis L, Avela J, Hakkinen K. Neuromuscular fotigue during dynamic maximal strength and hypertrophic resistance loadings. J Electromyogr Kinesiol. 2012;22(3):356-362. doi:10.1016/j.j.jelekin.2011.12.009

13. Nicholson G, Ispoglou T, Bissas A. The impact of repetition mechanics on the adaptations resulting from the strength-, hypertrophy- and cluster-type resistance training. Eur J Appl Phys 2016;116(10):1875-1888. doi:10.1007/s00421-016-3439-2

14. Drinkwater EJ, Lane T, Cannon J. Effect of an acute bout of plyometric exercise on neuromuscular fatigue and recovery in recreatio $2009 \cdot 23(4) \cdot 1181-1186$

15. Date AS, Simonson SR, Ransdell LB, Gao Y. Lactate response Different volume pattens of power clean. J Strength Cond Res. 2013;27(3):604-610.

16. Brown GA, Ray MW, Abbey BM, Shaw BS, Shaw I. Oxygen consumption, heart rate, and blood lactate responses to an acute bout of plyometric depth jumps in college-aged men and women. J Strength Cond Res. 2010;24(9):2475-2482. doi:10.1519/JSC. 0 b0 $13 \mathrm{e} 3181 \mathrm{~b} 22 \mathrm{~b} 63$

17. Chatzinikolaou A, Fatouros IG, Gourgoulis V, Avloniti A, Jamurtas A, Nikolaidis M, et al. Time course of changes in performance and inflammatory responses after acute plyometric exercise. J Strength Cond Res. 2010;24(5):1389-1398.

Skurvydas A, Kannandulis S, Masiulis N. Two series of fifty jumps and muscle damage. I Strength Cond Res. 2010:24(4):929-935. doi:10.1519/JSC.0b013e3181cb27ba.

19. Wertheimer V,Antekolovic L, Matkovic BR. Muscle damage indicators after the land and aquatic plyometric training programmes. Montenegrin J Sport Sci Med. 2018;7(1):13-19. doi:10.26773/ mjssm. 180302

. Wernbon M, Jas Acute effects of blood flow restriction on muscle activity and endurance during fatiguing dynamic knee extensions low load. J Strength Cond Res. 2009;23(8):2389-2395.

21. Okuno NM, Pedro RE, Leicht AS, de Paula Ramos S, Nakamura FY. Cardiac autonomic recovery after a single session of resistance exercise with and without vascular
oclusion. J Strength Cond Res. 2014:28(4):1143-1150. doi:10.1519/JSC 00000000000000245 .

2. Poton R, Polito MD. Hemodynamic response to resistance exercise with and without blood flow restriction in healthy subjects. Clin Physiol Funct Imaging. 2016;36(3):231-236. doi:10.1111/cpp.12218.

23. de Almeida B, Aidar FJ, de Matos DG, Almeida Junior H, Boaretto SM, Souza RF. Comparison of Traditional Strength Training and Kaatsu Strength Training on Thermal Asymmetry, Fatigue Rate, and Peak Torque. J Exerc Physiol Online. 2017;20(1):1-12. http://search.ebscohost.com/login.aspx?direct=true\&db=s3h\&AN=121047615\&lang=es\&site $=\mathrm{e}$ host-live\&scope=site.

Gadruni K, Mahmmadpour H, Gadruni M. Effect of elasresponses in taekwondo athletes. Rev Bras Med do Esporte. 2015;21(4):297-301.

25. Fernandez-Gonzalo R, Lundberg TR, Alvarez-Alvarez L, de Paz JA. Muscle damage responses and adaptations to eccentric-overload resistance exercise in men and women. Eur J Appl Physiol. 2014;114(5):1075-1084. doi:http://dx.doi. org/10.1007/s00421-014-2836-7.

26. Oliveira AS, Greco CC, Pereira MP, Figueira TR, Ruas VDA, Goncalves M, Denadai BS. Physiological and neuromuscular profile during a body pump session: acute responses during a high-resistance training session. J Strength Cond Res. 2011;25(12):3422-

Greco CC, Oliveria AS, Pereira MP, Figueira TR, Ruas VDA, Goncalves M, Denadai BS. Improvements in metabolic and J Strength Cond Res. 2011;25(12):3422-3431. doi:10.1519. JSC.0b013e3182160053.

28. Ojeda ÁH, Maliqueo SG, Barahona-Fuentes G, López JC. Phys Ther Sci. 2019;31(7):512-515.

9. Ojeda A, Rios LC, Barrilao RG, Ojeda XH. Behavior of corissol, $\mathrm{CK}$, and lactate in a session of variable resistance. Rev Bras Med do Esporte. 2018;24(4):268-272.

. Kamandulis S, Snieckus A, Venckunas T, Aagaard P, Masiulis , Skurvydas A. Rapid Ancrease in training load affects markJ Strenth Cond Res. 2012:26(11):2953-2961.

31. Bigland-Ritchie B. EMG/force relations and fatigue of human voluntary contractions. Exerc Sport Sci Rev. $1981,9(1) .75-118$. an Indicator of Neuromuscular Fatigue during Resistance Training. Med Sci Sports Exerc. 2011;43(9):1725-1734.

33. Izquierdo M, Gonzalez-Izal M, Navarro-Amezqueta I, Calbet JAL, Ibañez J, Malanda A, et al. Effects of Strength Training on Muscle Fatigue Mapping from Surface EMG and Blood Metabolites. Med Sci Sports Exerc. 2011:43(2):303-311.
34. Walker S, Ahtiainen JP, Hakkinen K. Acute neuromuscular and hormonal responses during contrast loading: effect of 11 weeks of contrast training. Scand J Med Sci Sports. 2010;20(2):226234. doi:10.1111/j.1600-0838.2009.00914.x

35. Hardee JP, Lawrence MM, Utter AC, Triplett NT, Zwetsloot KA, McBride JM. Effect of inter-repetition rest on ratings of Fur J Appl Physiol. 2012:112(8):3141-3147. doi http:/dx doi. org/10.1007/s00421-011-2300-x.

36. Evangelista R, Pereira R, Hackney AC, Machado M. Rest inerval between resistance exercise sets: leng but not creatine kinase activity or muscle soreness. Int J Sports Physiol Perform. 2011;6(1):118-127. https://search.proquest. com/docview/862005352?accountid $=14542$.

37. Buitrago S, Wirtz N, Yue Z, Kleinöder H, Mester J. Effects of load and training modes on physiological and metabolic responses in resistance exercise. Eur J Appl Physiol. 2012;112(7):2739-2748. doi:http://dx.doi.org/10.1007/ s00421-011-2249-9.

38. Moher D, Liberati A, Tetzlaff J, Altman DG. Preferred reporting items for systematic reviews and meta-analyses: the
PRISMA statement. Ann Intern Med. 2009:151(4):264-269.

39. Maher CG, Sherrington C, Herbert RD, Moseley AM, Elkins M. Reliability of the PEDro Scale for Rating Quality of Randomized Controlled Trials. Phys Ther. 2003;83(8):713721. doi:10.1093/ptj/83.8.713.

40. de Morton NA. The PEDro scale is a valid measure of the

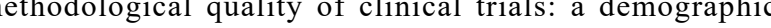
study. Aust J Physiother. 2009;55(2):129-133. doi:https://doi. org/10.1016/S0004-9514(09)70043-1

41. Thomas K, Brownstein CG, Dent J, Parker P, Goodall S, Howatson G. Neuromuscular Fatigue and Recovery after Exerc. 2018:50(12):2526-2535.

42. Curty VM, Melo $A B$, Calds LC, Guimarães-Ferreira L Sousa $\mathrm{NF}$, Vassallo PF, et al. Blood flow restriction attenuates eccentric exercise-induced muscle damage without pereeptual and cardiovascular overload. Clin Physiol Funct Imaging. 2018;38(3):468-476. doi:10.1111/cpf.12439.

43. Sieljacks P, Degn R, Hollaender K, Wernbom M, Vissing K. Non-failure blood flow restricted exercise induces similar muscle adaptations and less discomfort than failure proto2018. doi:10.1111/ sms. 13346

44. Ojeda ÁH, Chirosa LJ, Barrilao RG, Rios IJC, Serrano PAC Efecto de la resistencia variable sobre la potenciación post Rev la Fed Espanola Med del Deport y la Confed Iberout (17)

Rogatzki MJ, Wright GA, Mikat RP, Brice AG, Blood ammonium and lactate accumulation response to different training protocols using the parallel squat exercise. J Strength Cond Res. 2014

46. Parraga-Montilla JA, Garcia-Ramos A, Castano-Zambudio A, Capelo-Ramírez F, González-Hernández JM, CorderoRodríguezet $\mathrm{Y}$, et al. Acute and Delayed Effects of a

Motriz, Rio Claro, v.26, Issue 3, 2020, e1020006
Resistance Training Session Leading to Muscular Failure on Mechanical, Metabolic, and Perceptual Responses. J Strength Cond Res. June 2018. doi:10.151 JSC.

47. Silva RAS, Silva-Júnior FL, Pinheiro FA, Souza PFM, Boullosa DA, Pires FO. Acute prior heavy strength exercise Strength Cond Res. 2014:28(9):2513-2520. doi:10.1519/ JSC. 0000000000000442 .

48. Andreatta MV, Curty VM, Coutinho JVS, Santos MAA, Vassalo PF, Sousa NF, et al. Cell-Free DNA as an Earlier Predictor of Exercise-Induced Performance Decrement Related to Muscle Damage. Int J Sports Physiol Perform. 2018;13(7):953-956. doi:10.1123/ijspp.2017-042

49. Bartolomei S, Sadres E, Church DD, Arroyo E, Gordon III JA, Varanoske NA, et al. Comparison of the recovery response from high-intensity and high-volume resistance exercise in trained men. Eur $J$ Appl Physiol. s00421-017-3598-9.

50. Moran-Navarro R, Perez CE, Mora-Rodriguez R, la Cruz-Sanchers E, Gonzalez-Badillo JJ Sanchez-Media L, et al. Time course of recovery following resistance training leading or not to failure. Eur J Appl Physiol. 2017;117(12):2387-2399.

51. Smilios I, Hakkinen K, Tokmakidis SP. Power output and electromyographic activity during and af ter a moderate load muscular endurance session. Strength Cond Res. 2010;24(8):2122-2131. doi:10.1519/ JSC.0b013e3181asbc44.

52. Gauche E, Couturier A, Lepers R, Michaut A, Rabita G, Hausswirth C. Neuromuscular fatigue following high muscle. J Electromyogr Kinesiol. 2009:19(6):481-486. doi:10.1016/j.jelekin.2009.01.006.

53. Raeder C, Wiewelhove T, Simola RA, Kellmann M, Meyer T, Pfeiffer M, et al. Assessment of Fatigue and Recovery in Male and Female Athletes After 6 Days of Intensified Strength Training. J Strength Cond Res. 2016;30(12):34123427. doi:10.1519/JSC. 0000000000001427

54. Paulo CA, Roschel H, Ugrinowitsch C, Kobal R, Tricoli V. Influence of different resistance exercise loading scheme on mechanical power output in work to rest ratio - equaed and - nonequated conditions. J Strength Cond Res. 2012;26(5):1308-1312

, Maia M, de Oliveira CG, Farias D, Silva JB, Lima $\mathrm{VP}$, et al. Myoelectric indices of fatigue adopting dif2018;22(1): 178-183. doi:S1360-8592(17)30044-X.

56. Miranda H, Souza JAAA, Scudese E, Paz GA, Salerno VP, Vigario PS, et al. Acute Hormone Responses Subsequent
to Agonist-Antagonist Paired Set vs. Traditional Straight Set Resistance Training. J Strength Cond Res. July 2018. doi: 10.1519/JSC.0000000000002633.

57. Tufano JJ, Conlon JA, Nimphius S, Oliver JM, Kreutzer A, Haff GG. Different Cluster Sets Result In Similar
Metabolic, Endocrine, And Perceptual Responses 
In Trained Men. J Strength Cond Res. March 2019. doi:10.1519/JSC.0000000000001898.

58. Ammar A, Chtourou H, Trabelsi K, Padulo J, Turki M, El Abed $\mathrm{K}$, et al. Temporal specificity of training: intra-day effects on biochemical responses and Olympic-Weightlifting performances. J Sports Sci. 2015;33(4):358-368. doi:10.108 0/02640414.2014.944559.

59. Taipale RS, Schumann M, Mikkola J, Nyman K, Kyrolainen $\mathrm{H}$, Nummela AT, et al. Acute neuromuscular and metabolic responses to combined strength and endurance loadings: the 'order effect' in recreationally endurance-trained runners. J Sports Sci. 2014;32(12):1155-1164. doi:10.1080/02640414. 2014.889842.

60. Johnston M, Johnston J, Cook CJ, Costley L, Kilgallon M, Kilduff LP. The effect of session order on the physiological, neuromuscular, and endocrine responses to maximal speed and weight training sessions over a 24-h period. J Sci Med Sport. 2017;20(5):502-506.

\section{Corresponding author}

Guillermo D. Barahona-Fuentes

Camino del Sol 2.300, Condominio Paso Hondo IV, Casa H1, Quilpué, Chile. Mobile phone: +56963989823

E-mail: danielbarahonaf@gmail.com

Editor: Angelina Zanesco, UNESP/Rio Claro, SP, Brazil

Manuscript received on April 15, 2020

Manuscript accepted on May 2, 2020

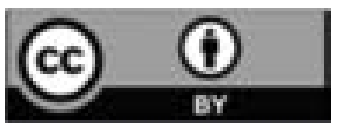

Motriz. The Journal of Physical Education. UNESP. Rio Claro, SP, Brazil - eISSN: 1980-6574 - under a license Creative Commons - Version 4.0 